\title{
A multitracer approach to assess the spatial contamination pattern of hake (Merluccius merluccius) in the French Mediterranean
}

\author{
Cresson Pierre ${ }^{1,2,{ }^{*}}$, Bouchoucha Marc ${ }^{2}$, Morat Fabien ${ }^{3}$, Miralles Francoise ${ }^{2}$, Chavanon Fabienne ${ }^{2}$, \\ Loizeau Veronique ${ }^{4}$, Cossa Daniel ${ }^{5}$
}

${ }^{1}$ Ifremer, RHMN, Centre Manche - Mer du Nord, BP 669, F-62 321 Boulogne sur Mer, France

2 Ifremer, LER/PAC, Centre de Méditerranée, CS 20330, F-83 507 La Seyne sur Mer, France

${ }^{3}$ IRSTEA, 3275 Route Cézanne, CS 40061, F-13 182 Aix en Provence Cedex 5, France

4 Ifremer, LBCO, Centre Atlantique, BP 70, F-29 280 Plouzané, France

${ }^{5}$ ISTerre, Université Joseph Fourier, BP 53, F-38 041 Grenoble, France

*Corresponding author : Pierre Cresson, email address : pierre.cresson@ifremer.fr

\begin{abstract}
:
Chemical contamination levels and stable isotope ratios provide integrated information about contaminant exposure, trophic position and also biological and environmental influences on marine organisms. By combining these approaches with otolith shape analyses, the aim of the present study was to document the spatial variability of $\mathrm{Hg}$ and PCB contamination of the European hake (Merluccius merluccius) in the French Mediterranean, hypothesizing that local contaminant sources, environmental conditions and biological specificities lead to site-specific contamination patterns. High $\mathrm{Hg}$ concentrations discriminated Corsica (average: $1.36 \pm 0.80 \mu \mathrm{g} \mathrm{g}-1 \mathrm{dm}$ ) from the Gulf of Lions (average values < $0.5 \mu \mathrm{g} \mathrm{g}-1 \mathrm{dm}$ ), where Rhône River input caused high PCB burdens. CB 153 average concentrations ranged between $4.00 \pm 0.64$ and $18.39 \pm 12.38 \mathrm{ng} \mathrm{g}-1 \mathrm{dm}$ in the Gulf of Lions, whatever the sex of the individuals, whereas the highest values in Corsica were $6.75 \pm 4.22 \mathrm{ng} \mathrm{g}-1 \mathrm{dm}$. Otolith shape discriminated juveniles and adults, due to their different habitats. The use of combined ecotracers was revealed as a powerful tool to discriminate between fish populations at large and small spatial scale, and to enable understanding of the environmental and biological influences on contamination patterns.
\end{abstract}




\section{Graphical abstract}

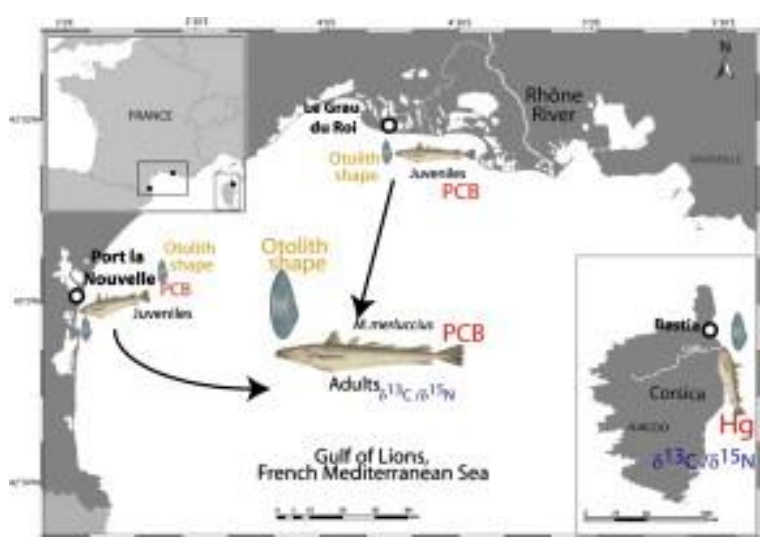

\section{Highlights}

- Hg and PCB concentrations were assessed in French Mediterranean hake. Stable isotope and otolith shape analyses were used in combination. Local isotopic and contamination patterns were observed. Hg values were high in Corsica, PCB in the Gulf of Lions. Combined ecotracers are powerful to discriminate between local populations.

Keywords : Hg, Mediterranean, Merluccius merluccius, Multiple ecotracers, PCB 


\section{Introduction}

The release of chemical contaminants in the marine environment is one of the main threats currently altering marine individuals, populations and ecosystems (Fitzgerald and Clarkson, 1991; Fleeger et al., 2003; Halpern et al., 2008; Tartu et al., 2013). This issue is of particular concern in the Mediterranean Sea, as the numerous highly-populated and industrialized countries around this sea exert a strong pressure on it (Durrieu de Madron et al., 2011). Amongst all contaminants, mercury $(\mathrm{Hg})$ and polychlorobiphenyls (PCB) are of particular concern. Mercury is emitted in the environment as a volatile metal $\left(\mathrm{Hg}^{0}\right)$ of both natural and anthropogenic origins, with a three-fold increase in anthropic emissions since the industrial era (Streets et al., 2011; UNEP, 2013; Lamborg et al., 2014). After deposition, as $\mathrm{Hg}^{\prime \prime}, \mathrm{Hg}$ is transformed by bacteria into methylmercury (MeHg), its bioamplifiable and toxic form. The case of $\mathrm{Hg}$ is peculiar in the Mediterranean, as biogeochemical and biological features of this sea cause the "Mediterranean mercury anomaly", i.e. higher $\mathrm{Hg}$ concentrations in Mediterranean organisms than in conspecifics from other environments, whereas $\mathrm{Hg}$ concentrations in water or sediment do not differ (Aston and Fowler, 1985; Cossa and Coquery, 2005; Cossa et al., 2009, 2012; Harmelin-Vivien et al., 2009; Heimbürger et al., 2010). Polychlorinated biphenyls (PCBs) are a group of synthetic organochlorinated compounds which have been produced as commercial technical mixtures since the 1920s. They have been used in a wide range of applications, such as coatings, inks, flame retardants and paints, but their major applications were in electric appliances, heat transfer systems and hydraulic fluids. PCB open applications were banned in many countries in the 1970's but remained in use in closed systems (such as capacitors and transformers) before a complete ban in the 1990's. However, their high lipophilicity and environmental stability make them persist in the environment for long periods, resulting in a wide geographical distribution. These compounds are considered among the most dangerous pollutants because of their toxicity (Ahlborg and Hanberg, 1994; Loonen et al., 1996) stability, long biological half-life, and high liposolubility. A decrease of PCB concentrations in biota is thus currently expected (Aguilar and Borrell, 2005), but few long-term studies are available to document this trend. Both $\mathrm{MeHg}$ and PCBs are bioaccumulable and biomagnifiable along food chains, with a potential risk for high trophic level predators (Borgå et al., 2001; Fisk et al., 2001; Nfon and Cousins, 2006).

Since consuming contaminated marine products is the main source of human contamination (Fitzgerald and Clarkson, 1991; Endo et al., 2013), most studies were dedicated to assessing this risk, by documenting crude $\mathrm{Hg}$ or PCB levels in marine products, with little interest in the underlying biological or environmental processes (e.g. Bocio et al., 2007; Storelli, 2008; Storelli and Barone, 2013). Chemical contaminants emerged recently as useful ecotracers of trophic patterns or environmental parameters when used in combination with other tools, mostly stable isotope analyses (Fisk et al., 2002; Chouvelon et al., 2014; Cresson et al., 2014; Brown et al., 2015; Lavoie et al., 2015). This combined approach has become classical, since the $C$ and $N$ stable isotope ratio or the contaminant level of a fish is dependent upon its diet and the two techniques provide complementary time- and space-integrated information about trophic patterns. The nitrogen isotopic ratio and contaminant burden increase with trophic level providing combined information about the position of an organism in the trophic web. In a similar way, contaminant analyses can discriminate between two organic matter (OM) sources with similar isotopic ratios but different contamination levels (Cresson et al., 2014; McMeans et al., 2014). Finally, contamination levels and stable isotope ratios are under the control of different metabolic and environmental processes, such as local contamination source, growth rate or primary production intensity (Fisk et al., 2001, 2002; Hoekstra et al., 2003; Bodiguel et al., 2009a, 2009b; Dierking et al., 2009; Cossa et al., 2012; Harmelin-Vivien et al., 2012a). Combining the results provided by these techniques was thus recently used as an effective tool to discriminate between different local populations influenced by different environmental conditions or contaminant sources (Carravieri et al., 2014; Chouvelon et al., 2014; Brown et al., 
2015; Lavoie et al., 2015). In a similar way, analyzing the shape of otoliths provides information about the local environmental conditions. Otoliths ("earstones") are calcified pieces of the inner ear of teleosts (ray-finned fishes), the general shape of which is species-dependent. At a fine scale, within-species variation of the shape can reveal the influence of environmental parameters such as temperature and/or food availability (Lombarte and Lleonart, 1993; Gagliano and McCormick, 2004; Mérigot et al., 2007; Morat et al., 2012b). Despite being a promising approach, otolith shape, contaminant, and stable isotope analyses have not to date been used in combination.

In the French Mediterranean, the Gulf of Lions is an area of great ecological and economic importance but also of great concern, and under the major influence of the Rhône River. On the one hand, the Rhone River watershed is highly populated and industrialized, and the river is an important source of contaminants to the Gulf of Lions (Miralles et al., 2006; Radakovitch et al., 2008; Cossa et al., 2014; Mourier et al., 2014). The Rhone River is considered notably as an important source of PCB, due to the heavy historical contamination of the river's sediments by chemical industry wastes (Durrieu de Madron et al., 2011; Mourier et al., 2014). On the other hand, the Rhône River runoff is the main source of OM in the Gulf of Lions, enhancing the biomass production of harvested fish species (Salen-Picard et al., 2002). More than $90 \%$ of the French Mediterranean fisheries are located in the Gulf of Lions, with European hake (Merluccius merluccius Linnaeus, 1758) being the most important species (Aldebert et al., 1993; Bănaru et al., 2013). In the 1990's, the French fleet trawled 2220 metric tons ( $\mathrm{t}$ ) of hake annually (Aldebert et al., 1993). Nowadays, these catches range between 780 and $1500 \mathrm{t}$ (Ifremer Fisheries Information System, P. Lespagnol, pers. comm.). Captures are mostly composed of juvenile individuals $(13-14 \mathrm{~cm}$ ) trawled on the continental shelf, as adult individuals migrate to deeper zones (up to $800 \mathrm{~m}$ depth) when growing (Recasens et al., 1998; Maynou et al., 2003). Since their growth rate is slower (de Pontual et al., 2006; Mellon-Duval et al., 2010), males stay longer on the shelf, and are predominantly harvested, which explains the imbalanced sex-ratio and the predominance of female hake in the Gulf of Lions. The high trophic position of hake and its predominance in Mediterranean fisheries (Aldebert et al., 1993; Harmelin-Vivien et al., 2012a; Sinopoli et al., 2012; Bănaru et al., 2013) have made necessary extensive assessment of the contamination patterns. Recent studies in the Gulf of Lions identify sex, growth rate, reproduction and diet as key factors to explain the contamination patterns (Bodiguel et al., 2009a, 2009b; Mellon-Duval et al., 2010; Cossa et al., 2012; HarmelinVivien et al., 2012a). In particular, the lower burdens measured in females were explained by their faster growth which dilutes the contamination by a higher synthesis of tissues, and by the elimination of organic contaminants such as PCB during spawning (Bodiguel et al., 2009a).

Nevertheless, published studies have not investigated the spatial variation of PCB and $\mathrm{Hg}$ contamination in the French Mediterranean. In addition, the $\mathrm{Hg}$ and PCB concentration in Corsican fish have been poorly investigated (Porte et al., 2002; Cresson et al., 2015). Consequently, the aims of the present study were to document the spatial contamination pattern in Mediterranean hake, with a special focus on Corsica, in order to investigate whether contamination patterns can be considered as site-specific, and if they can discriminate between local populations, as previously observed for other species or environments (Dierking et al., 2009; Chouvelon et al., 2014). The use of combined biomarkers would allow understanding of the relative importance of each marker to discriminate the influence of local contamination sources from environmental and biological features. Notably, ontogenetic shift of habitat and of diet, bioaccumulation of contaminants through fish lifespan, PCB inputs from the Rhône River in the Gulf of Lions and oligotrophy in Corsica would be expected to be major drivers of the contamination patterns. 


\section{Material and methods}

\subsection{Sampling sites}

European hake (Merluccius merluccius) individuals were collected by professional trawlers at three sites of the French Mediterranean (Fig. 1), two in the western part of the Gulf of Lions (Port la Nouvelle and Le Grau du Roi) and one in northeastern Corsica (Bastia). These sites were chosen on the basis of the hypothesis that they reflect different contamination levels. Port la Nouvelle is considered as a site far from major anthropic influences and low levels of contaminants were measured in biota in this area (Dierking et al., 2009; Cresson et al., 2015). Le Grau du Roi is close to the Rhône River mouths and high levels of contamination would be expected (Bodiguel et al., 2009a; Dierking et al., 2009). The Bastia site in Corsica is located beyond the influence of the Gulf of Lions, with low urban and industrial development, and might consequently be expected to be a semi-pristine area (Porte et al., 2002; Galgani et al., 2006; Serrano et al., 2013). Samples were collected in the zone usually harvested by fishermen, on the continental shelf (between 50 and 80 meters depth) of the Gulf of Lions and along the shelf break in Corsica (between 300 and $450 \mathrm{~m}$ depth), as the continental shelf is thinner. Fishermen were asked to collect 10 individuals in each $5 \mathrm{~cm}$ size-class, between 10 and $50 \mathrm{~cm}$. Actual sampling size was lower due to technical constraint in the field and is detailed in Table S1. Sampling was performed within a short period of time (Sept. - Oct. 2013) at all sites, outside the main reproduction period of hake in the Mediterranean (Recasens et al., 1998; Belcari et al., 2006). After sampling, fish were stored frozen until dissection.

\subsection{Sample preparation and dissection}

In the lab, individuals were thawed, measured (total length, to the nearest $\mathrm{mm}$ ) and weighed (eviscerated mass, to the nearest $0.1 \mathrm{~g}$ ). Males and females were separated on the basis of macroscopic observation of the gonads. Small individuals with undifferentiated gonads were considered as juveniles. Fish body condition was determined using relative condition factor $\mathrm{Kr}$ (Le Cren, 1951), with $\mathrm{Kr}=\mathrm{M}_{\mathrm{e}} / \mathrm{M}_{\mathrm{e}}{ }^{\prime}$. Me is the measured eviscerated mass and $\mathrm{M}_{\mathrm{e}}{ }^{\prime}$ is the estimated eviscerated mass, calculated as $M_{e}{ }^{\prime}=10^{b} \times T^{a}$, using parameter $a$ and $b(a=$ 3.3631 and $b=-2.6568$ ) calculated by Ferraton et al. (2007) in the Gulf of Lions.

Three muscle samples without skin were collected for analyses, dorsal white muscle for stable isotope analyses, muscle from the caudal peduncle for $\mathrm{Hg}$ determination, and the whole remaining muscle for PCBs determination, as a large amount of matter is needed for this analysis. Muscle choice was driven by international standards (Pinnegar and Polunin, 1999; Nakhlé et al., 2007) and by laboratory experience (Cresson et al., 2014, 2015). Muscle samples were stored frozen before freeze-drying and grinding. Muscle samples dedicated to the analysis of PCB were stored in aluminum foil previously burned $\left(450^{\circ} \mathrm{C}, 6 \mathrm{~h}\right)$ to eliminate all OM traces. Sagittal otoliths were extracted from the cranial cavity to perform otolith shape analysis. Age determination based on otolith reading is not available for hake, as otolithbased age is overestimated (de Pontual et al., 2006). Age of the fishes was thus determined on the basis of length - age sex-specific relationships previously calculated for hake in the Gulf of Lions (Mellon-Duval et al., 2010).

\subsection{Isotopic and contaminant analyses}

$\mathrm{C}$ and $\mathrm{N}$ stable isotope ratios were determined with a continuous flow mass spectrometer (Delta V Advantage, Thermo Scientific, Bremen, Germany) coupled with an elemental analyzer (Flash EA 1112 Thermo Scientific, Milan, Italy). Results are expressed following the standard $\delta$ notation: 
$\delta X=\left(\frac{R_{\text {sample }}}{R_{\text {standard }}}-1\right) \times 10^{3}$, where $\mathrm{X}$ is ${ }^{13} \mathrm{C}$ or ${ }^{15} \mathrm{~N}$ and $\mathrm{R}$ the ratio ${ }^{13} \mathrm{C} /{ }^{12} \mathrm{C}$ or ${ }^{15} \mathrm{~N} /{ }^{14} \mathrm{~N}$

respectively. Accuracy of the measurement was checked by repeated analyses of internal samples of acetanilide and was lower than $0.1 \%$ for $\mathrm{C}$ and $\mathrm{N}$. $\mathrm{C} / \mathrm{N}$ ratios were determined with the elemental analyzer and used as a proxy of the lipid content of the samples. All samples displayed $\mathrm{C} / \mathrm{N}$ values lower than the 3.7 value (Sweeting et al., 2006) considered as a threshold for a lipid bias and requiring a correction of isotopic ratios. One determination of $\delta^{13} \mathrm{C}$ and $\delta^{15} \mathrm{~N}$ was performed for each individual.

Total $\mathrm{Hg}$ concentration was determined by the semi-automated atomic absorption spectrophotometer (AMA-254, Altec Ltd., Praha, Czech Republic) in three steps (1) sample high temperature $\left(550^{\circ} \mathrm{C}\right)$ burning and mercury evaporation, (2) trapping of the $\mathrm{Hg}$ on a gold trap and (3) heating $\left(800^{\circ} \mathrm{C}\right)$ of the trap, sweeping of trapped $\mathrm{Hg}$ in the flow cell before determination of $\mathrm{Hg}$ amount by spectrophotometric atomic absorption. The accuracy of the analysis is assessed with a standard certified material (DORM-4, National Research Council of Canada) chosen in accordance with the assumed $\mathrm{Hg}$ content of the sample. Certified material is tested for every ten fish samples. Measured values were always within the confidence limits of the certified materials (certified values: $0.410 \pm 0.055 \mu \mathrm{g} \mathrm{g} \mathrm{g}^{-1}$; found values: $\left.0.389 \pm 0.008 \mu \mathrm{g} \mathrm{g}^{-1}\right)$. This technique allows the determination of the total $\mathrm{Hg}$ but not the methylmercury (MeHg). However, total $\mathrm{Hg}$ is a good proxy of $\mathrm{MeHg}$, as $\mathrm{MeHg}$ represents 70 to $100 \%$ (mean value: $98 \%$ ) of total $\mathrm{Hg}$ in hake (Storelli et al., 2005; Cossa et al., 2012). Concentrations are expressed relative to the dry mass $(\mathrm{dm})$ of individuals. One determination of $\mathrm{Hg}$ concentration was performed for each individual.

PCBs were determined following analytical procedures in accordance with standard NF ISO 10382 and XP X33-012 and summarized below. A precisely weighed amount of the powdered muscle, $2 \mathrm{~g}$ dry mass, was extracted with acetone, pentane and iso-octane in acid medium with liquid-solid extraction ultrasonic extraction method. For small juvenile individuals, the required amount of muscle was obtained by pooling samples resulting from several similar individuals (same origin, age and size-class). 178 analyses of PCB concentrations were run. The samples were spiked with recovery standards (CB 29 for CB 28 analysis, CB 103 for other PCBs). The solution was purified by adsorption chromatography on a Florisil column eluted with pentane. GC-MS/MS determination was carried out on a GC 7890A (Agilent) with mass spectrometry detection (MS/MS, 7000GCTQD, Agilent), equipped with capillary column HP MS $30 \mathrm{~m}$ x $0.25 \mathrm{~mm}$ i.d. x $0.25 \mu \mathrm{m}$ film thickness (19091S-433).

Quantification was performed with a six-point calibration curve, based on standard samples of known concentrations (between $0.09-73 \mathrm{ng} \mathrm{g}^{-1}$ wet mass for PCB). Nine PCB congeners were analyzed in this work, the classical 7 PCB indicators defined by ICES (CB 28, 52, 101, 118 138, 153, 180 - referred hereafter as $\Sigma 7$ ) in addition to two "dioxin-like" congeners (CB 105 and 156), describing compounds with 3 to 7 chlorine molecules. Concentrations were expressed in $\mathrm{ng} \mathrm{g}^{-1}$ dry mass. All values measured for CB 28 were lower than the detection limit $\left(0.5 \mathrm{ng} \mathrm{g}^{-1}\right)$ and were not taken into consideration in the analysis. Similarly, and consistently with the classical approach (Bodiguel et al., 2008, 2009b; Harmelin-Vivien et al., 2012a), patterns observed for CB 153 were considered representative of the patterns observed for all congeners. The contamination profile was considered as the proportion of each chlorination class in the total PCB contamination. Measurement accuracy was checked by the analysis of certified samples, with standard deviations of $\sim 20 \%$ for all congeners. In addition, linearity of the regression curve was systematically verified before analyzing each new sample series, so as analytical blanks. During the analysis of the real samples, analytical blanks were systematically measured every 10 samples. The blank concentrations were always below the concentrations of the lowest standards of all congeners. Finally, a 
reference material (SRM 2974a, mussel tissue) was repeatedly analyzed. PCB recoveries varied between 67 to $111 \%$.

\subsection{Otolith shape analysis}

Prior to shape analysis, otoliths were oriented in the same direction and digitalized with a digital camera coupled with a stereomicroscope. The shape of the otolith was analyzed by the elliptic Fourier analysis, as described in Morat et al. (2012b), on a dataset of 194 right otoliths. Briefly, this technique allows the transformation of the complex shape of the otolith into a set of numerical descriptors, called harmonics. Each harmonic is characterized by 4 coefficients, resulting from the projection of each point of the outline on axes $(x)$ and $(y)$. The first harmonic is a simple ellipse. Increasing the number of harmonics increases the complexity of the shape and thus the accuracy of the numerical description of the original shape. The lowest needed number of harmonics was determined by calculating the Fourier Power (FP) spectrum. For the $\mathrm{n}^{\text {th }}$ harmonic, Fourier Power is given by the expression $F P_{n}=$ $\left(A_{n}^{2}+B_{n}^{2}+C_{n}^{2}+D_{n}^{2}\right) / 2$, with $\mathrm{A}, \mathrm{B}, \mathrm{C}$, and $\mathrm{D}$ the four coefficients of the $\mathrm{n}^{\text {th }}$ harmonic. The cumulated power percentage $\mathrm{FP}_{\mathrm{c}}$ is calculated as the sum of the powers of the $\mathrm{n}$ harmonics. The threshold of $99.99 \%$ for the cumulated power was reached for the $12^{\text {th }}$ harmonic. As the first harmonic is an uninformative perfect ellipse which masks information from the others, it was discarded and the following 11 harmonics and the 44 resulting Fourier coefficients were used.

\subsection{Numerical analyses}

The variability of biometry, isotopic ratios and contamination levels were analyzed independently across sex and origin using a univariate PERMANOVA (Anderson, 2001). Asymmetrical design was used with all factors treated as fixed. Total length, $\mathrm{Hg}$ and CB153 concentrations were log $(X+1)$ transformed prior to analyses. Euclidean distance similarity matrices were generated. Since length can affect diet and contamination levels, effect of sex and origin on isotopic ratios and contamination levels was checked twice with or without length as a covariate, but was discussed considering the most appropriate analyses, i.e. without covariate to assess the effect of sex (since the smaller size of juvenile reflect biological differences) but with covariate for spatial comparisons (since the difference in sizeclass distribution between sites is due to sampling). P-values were calculated by 9999 random permutations of residuals under a reduced model and Type III sum of square (Anderson, 2001). Significance was set at $p$-value $=0.05$. Analyses were performed using the PRIMER 6 software and the PERMANOVA add-on (Clarke and Warwick, 2001). The best fitting relation (linear or exponential) between length or $\delta^{15} \mathrm{~N}$ and $\mathrm{Hg}$ or PCB concentration was determined with Generalized Linear Models as the one minimizing the Aikake Information Criterion while being significant ( $p$-value $<0.05)$.

Numerical analyses about right otolith shape were performed following the methodology described in Morat et al (2012b) using a canonical discriminant analysis (CDA) based on the 44 Fourier coefficients. CDA allows verification of the integrity of groups defined a priori, and based here on geographical origin and degree of maturity (i.e. juveniles vs. adults at all sites). The performance of the analysis was assessed by the Wilks $\lambda$, which is a ratio between the intragroup and the total variances. Wilks $\lambda$ range between 0 and 1 , the lower the better discriminating power of the CDA. Distances between groups on the CDA representation were assessed calculating Euclidean distances between the barycenter of each group. The rate of good classification of the individuals within their pre-attributed group was assessed by a Cohen's kappa test.

Finally, the relative importance of each parameter in the general pattern was assessed by a CDA based on stable isotope ratios, log-transformed $\mathrm{Hg}$ and PCB concentrations, since logtransformation limits the importance of outlier values, and the coordinates of otoliths in the 
first two axes of the dedicated CDA. Rather than by the whole harmonics, otolith shapes were represented by the two first coordinates of the CDA that best represent variation of this descriptor. A priori groups were based on sex (juvenile, male or female) and on origin. Analyses were run with $\mathrm{R}$ software and "ade4" package (Chessel et al., 2004; R Core Team, 2014).

\section{Results}

\subsection{Sample size, sex ratio and morphological indices}

A total of 224 individuals was sampled (69 at Le Grau du Roi, 70 at Port la Nouvelle and 85 in Bastia). Average total length was close to $270 \mathrm{~mm}$ (Table 1) and not significantly different between sites (PERMANOVA $F=2.16, p=0.12$; Table S2). The sex ratio was largely imbalanced, with predominance of juvenile individuals in the smallest size-classes, and of females for larger individuals, consistently with the biology of the species. The pattern of length is nevertheless dependent on the sex and of the sampling location (PERMANOVA $F=$ 4.11, $p=0.003$ ). Mean length of males and females from Port la Nouvelle and Bastia did not significantly differ ( $300 \mathrm{~mm}$ TL for both sexes), whereas females from Le Grau du Roi were significantly larger than males (335 mm for females vs. $259 \mathrm{~mm}$ for males). Consequently, since males' growth rate is slower, males were older than females in Port la Nouvelle and Bastia, whereas males and females were of similar age in Le Grau du Roi (PERMANOVA F $=4.75, p=0.0001$ ). Fish condition factor varied also with site (lowest condition indices at Bastia, highest at Le Grau du Roi) and sex (highest condition factor for juveniles, no differences between adults of both sexes; Table 1)

\subsection{Carbon and nitrogen stable isotope ratios}

Isotopic values ranged between -19.91 and $-18.29 \%$ for $\delta^{13} \mathrm{C}$ and between 7.10 and 10.75 $\%$ for $\delta^{15} \mathrm{~N}$. When considering sites separately, the difference between minimum and maximum $\delta^{15} \mathrm{~N}$ values was close to $2 \%$. Origin and sex had an effect on stable isotope ratios (Fig. 2). Isotopic ratios were significantly lower for individuals collected at Bastia than in the Gulf of Lions (PERMANOVA $F=24.04$ for $\delta^{13} \mathrm{C}, \mathrm{F}=136.98$ for $\delta^{15} \mathrm{~N}, \mathrm{p}<0.0001$ in both cases). Juveniles exhibited significantly lower $\delta^{13} \mathrm{C}$ and $\delta^{15} \mathrm{~N}$ values than adults regardless of their origin, even if the trend was less marked at Bastia (PERMANOVA $F=$ 49.32 for $\delta^{13} \mathrm{C}$ and $\mathrm{F}=32.85$ for $\delta^{15} \mathrm{~N}, \mathrm{p}<0.0001$ in both cases). In addition, isotopic ratios measured for adults sampled at Bastia were not markedly different from those of juveniles but significantly lower than those of adults collected in the Gulf of Lions. Significant correlation between length and $\delta^{15} \mathrm{~N}$ were observed at Port la Nouvelle $\left(\delta^{15} \mathrm{~N}=6.95+0.009\right.$ TL, $r^{2}=0.66, p$-value < 0.0001) at Le Grau du Roi $\left(\delta^{15} \mathrm{~N}=8.31+0.004 \mathrm{TL}, \mathrm{r}^{2}=0.48, p-\right.$ value $<0.0001)$ and at Bastia $\left(\delta^{15} \mathrm{~N}=7.02+0.005 \mathrm{TL}, \mathrm{r}^{2}=0.37\right.$, $\mathrm{p}$-value $\left.<0.0001\right)$.

\subsection{Mercury concentrations}

Measured $\mathrm{Hg}$ values ranged between 0.10 and $5.03 \mathrm{\mu g} \mathrm{g}^{-1}$ (dry mass). A higher value (14.04 $\mu \mathrm{g} \mathrm{g}^{-1} \mathrm{dm}$ ) was measured for a large female (> $850 \mathrm{~mm} \mathrm{TL}$ ) collected at Le Grau du Roi, but this individual was not included in the study due to its lack of representativeness.

The most striking feature observed for $\mathrm{Hg}$ was the wide spatial difference (PERMANOVA $\mathrm{F}=$ $319.40, p<0.0001$ ), driven mostly by the high concentrations measured in Corsica. Mean $\mathrm{Hg}$ concentration at Bastia was notably higher $\left(1.36 \pm 0.80 \mu \mathrm{g} \mathrm{g}^{-1} \mathrm{dm}\right)$ than at Port la Nouvelle $\left(0.45 \pm 0.40 \mu \mathrm{g} \mathrm{g}^{-1} \mathrm{dm}\right)$ or at Le Grau du Roi $\left(0.29 \pm 0.18 \mu \mathrm{g} \mathrm{g}{ }^{-1} \mathrm{dm}\right)$. Differences between Corsica and Gulf of Lions were observed whatever the fish size but were more pronounced for larger individuals (Fig. 3). In the $15-20 \mathrm{~cm}$ size class, average values measured at 
Bastia were $\sim 0.6 \mu \mathrm{g} \mathrm{g}^{-1} \mathrm{dm}$ higher than values measured in the Gulf of Lions $(0.87 \pm 0.31$ $\mu \mathrm{g} \mathrm{g}^{-1} \mathrm{dm}$ at Bastia, $0.18 \pm 0.06 \mu \mathrm{g} \mathrm{g}^{-1} \mathrm{dm}$ at Le Grau du Roi and $0.20 \pm 0.10 \mu \mathrm{g} \mathrm{g}^{-1} \mathrm{dm}$ at Port la Nouvelle), whereas the difference was higher than $2 \mu \mathrm{g} \mathrm{g}^{-1} \mathrm{dm}$ for individuals larger than $40 \mathrm{~cm}\left(3.23 \pm 1.50 \mu \mathrm{g} \mathrm{g}^{-1} \mathrm{dm}\right.$ at Bastia, $1.02 \mu \mathrm{g} \mathrm{g}^{-1} \mathrm{dm}$ at Port la Nouvelle and $0.61 \pm$ $0.18 \mu \mathrm{g} \mathrm{g}^{-1} \mathrm{dm}$ at Le Grau du Roi). As a consequence, significant correlations were observed between length or trophic level and $\mathrm{Hg}$ concentrations, with the exponential model being the best fit in all cases except for the correlation between length and $\mathrm{Hg}$ at Port la Nouvelle (Fig. 3, Table S3).

\subsection{PCB concentrations}

The predominant part of the PCB contamination was represented by highly chlorinated compounds, whatever the sex and the origin of the fish. CB 153, 138 and 180 represent nearly $80 \%$ of the PCB contamination, with CB 153 representing more than $40 \%$ (Table 2). CB 153 concentration and $\sum 7$ were strongly correlated $\left(\sum 7=0.87+2.18\right.$ [CB 153]; $r^{2}=0.99$, p-value $<0.0001)$, justifying the use of this congener as a proxy of PCB contamination. In contrast, tri- and tetra-chlorinated congener were quite absent, with all CB 28 concentrations below detection limits, and CB 53 representing always less than $2 \%$ of the total PCB burden. Average CB 153 concentration was $8.85 \pm 8.58 \mathrm{ng} \mathrm{g}^{-1}$ dry mass, but with major variability, between sexes and sites. Individual concentrations ranged between 1.23 and $47.96 \mathrm{ng} \mathrm{g}^{-1}$ $\mathrm{dm}$. Regarding the sex, concentrations followed an increasing order: juveniles < females < males when all sites were combined. When sex and sites are considered, this pattern was conserved at Port la Nouvelle and Bastia, but females exhibited higher CB 153 concentrations than males at le Grau du Roi. This trend is observed for all PCB congeners (Fig. S1). Values measured at Bastia were lower than in the Gulf of Lions (PERMANOVA $F=26.80, p<0.0001$ ), where higher concentrations were measured at Port la Nouvelle when all sexes were considered together. This might result from the low values measured in males at le Grau du Roi, since females and juveniles collected at this site exhibited significantly higher CB 153 burdens than at Port la Nouvelle. Significant correlations were observed between CB 153 and length or trophic level in the Gulf of Lions, with the exponential model best fitting the data at Le Grau du Roi, and the linear model at Port la Nouvelle. At Bastia, CB 153 concentrations were not correlated with length or trophic level (Fig. 3, Table S2).

\subsection{Otolith shape}

The first plan of the CDA on Fourier coefficients explained $57 \%$ of the variability, with $\sim 75 \%$ of good reclassification (Cohen's kappa test). Results highlighted discrepancies between individuals from Corsica and the Gulf of Lions on the one hand, and between juveniles and adults on the other hand (Fig. S2). Wide differences (average value of Euclidean distances between barycenter of groups: $1.90 \pm 0.46$ ) were observed between individuals from Corsica and from the Gulf of Lions. The lowest Euclidean distance measured in the dataset was calculated between the barycenter of the groups formed by adults from both sites in the Gulf of Lions $(d=0.73)$. This value is lower than distances calculated between juveniles and adults from the same sites $(d=1.38$ at Port la Nouvelle and $d=2.11$ at Le Grau du Roi respectively) or between juveniles from both sites $(d=1.21)$. Finally, it is of interest to note that juveniles from Le Grau du Roi are very distant from other sites (Euclidean distances ranging between 2.09 and 2.59).

\subsection{Canonical discriminant analysis on combined parameters}

The general CDA based on all variables explained nearly $70 \%$ of the variability, and discriminated well the individuals, on the basis of their sex and their origin, since $67 \%$ were well-classified within the predefined group (Fig. 4). In addition, $20 \%$ of the remaining individuals were attributed to their actual site but to a wrong sex. The most efficient 
reclassification was observed for juveniles of both sites in the Gulf of Lions and for females from Port la Nouvelle (percentage of good reclassification $>70 \%$ ), whereas males from the Gulf of Lions were poorly reclassified. The first axis was based on the opposition between $\mathrm{Hg}$ and $\delta^{15} \mathrm{~N}$ values and discriminated individuals from Bastia vs. individuals from the Port la Nouvelle and Le Grau du Roi. The second axis was mostly based on the otolith shape parameters, and separated juveniles from adults at all sites, with a marked pattern in the Gulf of Lions.

\section{Discussion}

Stable isotope ratios, contamination levels and otolith shape allowed a clear discrimination between hake in the Gulf of Lions and in Corsica. Since contamination is mainly driven by the diet (Hall et al., 1997; Cresson et al., 2014) and as Hg and PCB are biomagnified through the trophic network, determining accurately the diet and trophic position of fish is crucial to understanding contamination patters. Additionally, contamination patterns are also driven by local contamination sources, the biology of the species, and environmental specificities (Bodiguel et al., 2009a; Cossa et al., 2012; Brown et al., 2015; Cresson et al., 2015). Assessing a site-specific contamination pattern thus requires a good understanding of all these parameters.

\subsection{The Rhône River, main driver of the pattern in the Gulf of Lions}

The Rhône River is the major organic matter (OM) and contaminant source for the Gulf of Lions. Its influence on coastal fish populations was previously demonstrated (Salen-Picard et al., 2002; Darnaude et al., 2004; Dierking et al., 2009; Morat et al., 2014). Results obtained for juvenile hake, whose habitat is shallower, smaller and more coastal than that of adults, confirmed this conclusion (Recasens et al., 1998; Maynou et al., 2003; Ferraton et al., 2007; Druon et al., 2015). Considering isotopic ratios, juveniles exhibited lower values than adults. This change could be explained by the ontogenetic change of diet (Ferraton et al., 2007; HarmelinVivien et al., 2012a, 2012b; Sinopoli et al., 2012). The correlation between $\delta^{15} \mathrm{~N}$ and length observed here is consistent with observations from other studies in the Mediterranean Sea or the Atlantic Ocean (Harmelin-Vivien et al., 2012a; Chouvelon et al., 2014). The other isotopic trend observed for juveniles is their $\delta^{13} \mathrm{C}$ value lower than that of adults. Change of $\delta^{13} \mathrm{C}$ observed between juveniles and adults could reflect the integration of land-derived OM in the trophic network of juvenile hake, whereas higher $\delta^{13} \mathrm{C}$ values for adults would be consistent with a greater importance of planktonic-derived OM. In the Gulf of Lions, riverine inputs are classically identified by low $\delta^{13} \mathrm{C}$ values - between -30 and $-25 \%$ - whereas phytoplankton range between -23 and -19\%o (Darnaude et al., 2004; Harmelin-Vivien et al., 2010; Cresson et al., 2012). Such an influence of riverine inputs on hake juveniles was previously observed at the mouth of the Rhône River, as juveniles collected closer to the river mouth exhibit lower $\delta^{13} \mathrm{C}$ values than individuals collected further offshore (Ferraton et al., 2007). At Port la Nouvelle, three coastal lagoons and several flash-flooding rivers could also represent important sources of land-derived OM (Kim et al., 2007). In Corsica, the Golo River may also represent a terrigenous OM source for juveniles (Mulder et al., 2003). These riverine inputs could also explain the higher condition factors calculated for juveniles than for adults. At Le Grau du Roi, massive amounts of OM washed down by the Rhône river would explain the highest condition factor measured, as well as the great differences in otolith shape, as previously observed for other species such as red mullet or common sole (Mérigot et al., 2007; Morat et al., 2012b). These amounts of OM would also be associated with inputs of PCB, explaining the higher values measured in females and juveniles at Le Grau du Roi. The predominance of highly-chlorinated congeners is consistent with a local source of PCB, since high chlorination precludes long-distance transport (Dierking et al., 2009; Brown et al., 2015). In 
contrast, the decreasing burdens in Port la Nouvelle would be consistent with the absence of a major local source in the western part of the Gulf of Lions (Dierking et al., 2009). The general trend of higher level of PCB in males than in females was also consistent with previous results, due to growth and reproduction discrepancies (Bodiguel et al., 2009a, 2009b; HarmelinVivien et al., 2012a). The trend measured at Le Grau du Roi consequently appeared as an oddity, as males exhibited an unexpectedly low PCB burden with regard to their sex and sampling location. Their smaller size and lower weight (Table 1, Fig. 2) might be an explanation for this low PCB burden, since trophic level, size and PCB contamination are directly correlated.

Finally, the influence of the Rhone River might explain the marked decrease of PCB concentrations observed between 2006 and the present (Harmelin-Vivien et al., 2012a). Values measured in 2013 were three to five times lower than values measured a decade ago (Table 3 ), consistently with the expected reduction of burdens in biota $\sim 25$ years after the ban on PCB use (e.g. Aguilar and Borrell, 2005). Nevertheless, the high order of magnitude of the decrease should be considered in relation with) the variation of the Rhône River inputs. Even if partial decontamination can occur through spawning (Bodiguel et al., 2009a), the PCB burden can be considered as representative of a long-term exposure to contaminants. Over the lifespan of the largest individuals collected in 2004 -2006 (i.e. at least 6 years, denoted by the grey zone in Fig. 5), seven flooding events were recorded (river discharge higher than $6000 \mathrm{~m}^{3} \mathrm{~s}^{-1}$, denoted by the arrows in Fig. 5), with a 100-year return flood (discharge higher than $10000 \mathrm{~m}^{3} \mathrm{~s}^{-1}$ ) in December 2003. These high water discharges represented massive inputs of OM integrated in the trophic webs (Salen-Picard et al., 2002; Darnaude et al., 2004; Morat et al., 2012a) but also of radionuclides (Miralles et al., 2006). It could be hypothesized that these flooding events also represented repeated inputs of PCB, leading to the high concentrations in the fish collected in 2004-2006. In the more recent period, flooding events were less frequent ( 3 flooding events in the 2006-2013 period) and of lower magnitude (< $\left.7000 \mathrm{~m}^{3} \mathrm{~s}^{-1}\right)$. The present PCB concentrations would thus represent a return to more "normal" values. Further long-term repeated surveys are thus needed to assess any actual decrease of PCB burdens.

\subsection{The "Corsican mercury anomaly", an effect of oligotrophy?}

Earlier studies on mercury concentrations in the Mediterranean documented a "Mediterranean mercury anomaly", i.e. higher Hg concentrations in Mediterranean individuals when compared with other oceans, even if concentrations in water or sediment were not significantly different (Aston and Fowler, 1985; Cossa and Coquery, 2005). Oligotrophy of the Mediterranean Sea was one of the main explanations of this discrepancy, as it drives the biogeochemical $\mathrm{Hg}$ cycle, the life history traits and the contamination pattern of the species (Cossa and Coquery, 2005; Harmelin-Vivien et al., 2009; Heimbürger et al., 2010; Cossa et al., 2012). At a lower spatial scale, the present study and recent works (Andral et al., 2004; Cresson et al., 2015) have contributed to documenting an analogous "Corsican mercury anomaly". Due to its low density of population and absence of large factories, Corsica is commonly considered as a semi-pristine area with low Hg or PCB concentrations (Porte et al., 2002; Galgani et al., 2006; Pergent et al., 2011; Serrano et al., 2013). In this context, the present high $\mathrm{Hg}$ values in hake muscle are unexpected and can be qualified as an "anomaly". But, similarly to the trend observed at a larger spatial scale throughout the Mediterranean (Aston and Fowler, 1985; Cossa and Coquery, 2005), oligotrophy may be the cause of the discrepancies observed for Corsican hake as it drives the biogeochemical cycle of $\mathrm{Hg}$ and the life history parameters of individuals.

From a biogeochemical point of view, the phytoplanktonic communities of Corsica are dominated by pico- and nanophytoplankton (Garrido et al., 2014). The presence of these small cells $(0.2$ to $20 \mu \mathrm{m})$ is associated with an enhanced methylation activity, leading to high 
amounts of MeHg (Heimbürger et al., 2010) and also to a lower biodilution of $\mathrm{Hg}$ in biogenic particles at the base of the trophic network (Cossa et al., 2012). Accordingly, higher amounts of $\mathrm{Hg}$ would be available for bio-magnification through the trophic network. Similarly, the predominance of small phytoplanktonic cells would explain the low isotopic ratios, as a significant correlation is observed between phytoplankton size and isotopic ratios. The lower the cell, the lower the isotopic ratios (Rau et al., 1990).

From a biological point of view, lower production leads to lower growth rate of organisms, thus lower bio-dilution of $\mathrm{Hg}$ contamination in newly synthesized tissues. Recent studies have documented the predominant effect of growth to explain the $\mathrm{Hg}$ concentration discrepancies in hake, between the Gulf of Lions and the Bay of Biscay in the Atlantic Ocean (Cossa et al., 2012), but also at a lower spatial-scale between the northern and the southern parts of the Bay of Biscay (Chouvelon et al., 2014). In hake, as otolith reading is not feasible, accurate assessment of the growth rate requires dedicated extensive work (e.g. de Pontual et al., 2006; Mellon-Duval et al., 2010). Nevertheless, low condition factors calculated in Corsica, whatever the sex, demonstrated a lower availability of nutritional resources. Similarly, the marked differences in otolith shape in Corsica might reflect different nutritional conditions, since food availability affects otolith shape (Gagliano and McCormick, 2004). The growth parameters calculated in the mesotrophic Gulf of Lions for faster-growing individuals might thus overestimate the age of Corsican fish. This could explain why the difference in $\mathrm{Hg}$ concentration between Corsica and the Gulf of Lions was higher for larger individuals. As they grow slower, Corsican large hake would be notably older than individuals of the same size in the Gulf of Lions. Their rather high $\mathrm{Hg}$ concentrations would thus reflect a longer exposure time. The presence of natural $\mathrm{Hg}$ sources along the Tuscan coast could also influence larger individuals which may consume prey with high $\mathrm{Hg}$ content, due to volcanic emissions (Barghigiani and de Ranieri, 1992). This influence is nevertheless restricted to the larger individuals with strong movement capacity, due to the distance between the coasts of Corsica and Tuscany $(\sim 100 \mathrm{~km})$. Finally, the deeper habitat of Corsican hake may have a synergistic effect on all the parameters studied, as oligotrophy increases with depth, and consequently reduce the growth rate, alter the otolith shape and isotopic ratios and increase $\mathrm{Hg}$ concentrations (Lombarte and Lleonart, 1993; Polunin et al., 2001; Choy et al., 2009; Drazen and Haedrich, 2012; Cresson et al., 2014).

\subsection{Combining multiple biomarkers to interpret contamination patterns and separate local populations}

In the recent years, contaminant analyses switched from a public health focused approach (i.e. assessing the risk of human contamination while consuming marine products) to an ecological approach (i.e. using contaminants as proxies of ecological processes). Combining stable isotope and contaminant analyses is nowadays classical as it covers both approaches. Adding otolith shape analyses has not been used so far in contamination studies but the results of the present study have demonstrated that it can be a powerful tool, since it provides a finer vision of the environmental parameters influencing trophic and contamination patterns at local scale.

At the large scale, the major difference observed between the Gulf of Lions and Corsica was mainly driven by the $\mathrm{Hg}$ and $\delta^{15} \mathrm{~N}$ difference, as denoted by the position of both groups in the first plan of the general CDA (Fig. 4). Oligotrophy, as it drives high $\mathrm{Hg}$ content and low $\delta^{15} \mathrm{~N}$ values in Corsica, thus appeared as the major environmental parameter to consider. The discriminating power of PCB was lower, but the good reclassification of females and the relative position of all groups from the Gulf of Lions (Le Grau du Roi on the right of Port la Nouvelle) seemed to demonstrate that it has nevertheless to be considered. The unexpectedly low values measured for males at Le Grau du Roi might have potentially blurred the signal and may explain why males were poorly reclassified. This discrimination 
within two subpopulations was consistent with the expected distribution pattern of hake in the French Mediterranean and the stocks management policy, with one population in the Gulf of Lions, and another in the Tyrrhenian Sea (GFCM, 2014). The use of contaminants has been previously successfully applied to separating subpopulations of marine species at a broad $(\sim 100 \mathrm{~km})$ geographical scale, on the basis of their proximity to a contaminant source or their different habitat use (Dierking et al., 2009; Carravieri et al., 2014; Chouvelon et al., 2014; Brown et al., 2015). These studies also confirmed that a combined approach is needed, and that isotopic or contaminant biomarkers alone are not sufficient. At a finer spatial scale, the use of otolith shape proved of major interest to characterize the different habitats between juvenile and adults in the Gulf of Lions. In contrast, the low difference between adults of the two sites might reflect some mixed populations and their occurrence in similar environmental conditions. With regard to Corsica, shape was not a major discriminating factor between adults and juveniles, even if conclusions might be limited by the low number of otolith shape analyses performed on juveniles. Nevertheless, it may be hypothesized that the limited width of the continental shelf in Corsica potentially limits the amount of shallow habitat favorable for juveniles and may impose the coexistence of adults and juveniles within the same habitat.

Combining contaminant, stable isotope and otolith shape analyses provided a basis for the refining of previous knowledge regarding hake contamination in the French Mediterranean, by adding a spatial and temporal component to earlier studies. It allowed discriminating between the Gulf of Lions and Corsica. PCB appeared as a major tracer of individuals collected in the Gulf of Lions, reflecting the integration of Rhône River inputs of OM and of contaminants in this zone. Consistently with previous results, oligotrophy was the main driver of the "Corsican Hg anomaly". In the whole of the French Mediterranean, the expected sitespecific contamination pattern confirmed the suitability of contaminants as effective tracers of local processes and thus capable of efficiently discriminating between local populations. The combined use of isotopic and otolith markers allows a finer discrimination, based on ontogenic shifts of habitat and diet. As the contamination profiles result from a synergistic effect of several biological and environmental parameters, the multimarker approach used in the present work proved a powerful tool to confirm the relative role of each parameter.

\section{Acknowledgement}

Thanks are expressed to our colleagues Benoit de Vogüe, Yoan Baldi and Serge Mortreux for their help with sampling, Patrick Lespagnol for hake landing statistics, Maryvonne Henry and Corine Tomasino for drawing of the map, and to the Companie Nationale du Rhône for Rhône river discharge data. Thanks are also expressed to the three fishermen for their participation in this project. Stable isotope analyses were performed at the LIENSs Laboratory, Université de la Rochelle by Gaël Guillou, Benoit Lebreton and Pierre Richard. PCB concentrations were measured at LABOCEA laboratory by Gaël Durand. This study is part of the RETROMED program, funded by grants $n^{\circ} 2013-0647$ from Agence de l'Eau Rhône Méditerranée Corse. Thanks are due to Michael Paul, a native English speaker, for English correction, and to two anonymous reviewers for their criticisms about a previous version of this paper. 
Aguilar, A., Borrell, A., 2005. DDT and PCB reduction in the western Mediterranean from 1987 to 2002, as shown by levels in striped dolphins (Stenella coeruleoalba). Marine Environmental Research 59, 391-404. doi:10.1016/j.marenvres.2004.06.004

Ahlborg, U.G., Hanberg, A., 1994. Toxic equivalency factors for dioxin-like PCBs. Chemosphere 1, 67-68.

Aldebert, Y., Recasens, L., Lleonart, J., 1993. Analysis of gear interactions in a hake fishery: the case of the Gulf of Lions (NW Mediterranean). Scientia Marina 57, 207-217.

Anderson, M.J., 2001. Permutation tests for univariate or multivariate analysis of variance and regression. Canadian Journal of Fisheries and Aquatic Science 58, 626-639.

Andral, B., Stanisiere, J.Y., Sauzade, D., Damier, E., Thebault, H., Galgani, F. et al. 2004. Monitoring chemical contamination levels in the Mediterranean based on the use of mussel caging. Marine Pollution Bulletin 49, 704-712. doi:10.1016/j.marpolbul.2004.05.008

Aston, S.R., Fowler, S.W., 1985. Mercury in the open Mediterranean: evidence of contamination? Science of the Total Environment 43, 13-26.

Bănaru, D., Mellon-Duval, C., Roos, D., Bigot, J.-L., Souplet, A., Jadaud, A., et al., 2013. Trophic structure in the Gulf of Lions marine ecosystem (north-western Mediterranean Sea) and fishing impacts. Journal of Marine Systems 111, 45-68.

Barghigiani, C., de Ranieri, S., 1992. Mercury content in different size classes of important edible species of the Northern Thyrrhenian Sea. Marine Pollution Bulletin 24, 114116.

Belcari, P., Ligas, A., Viva, C., 2006. Age determination and growth of juveniles of the European hake, Merluccius merluccius (L., 1758), in the northern Tyrrhenian Sea (NW Mediterranean). Fisheries Research 78, 211-217.

Bocio, A., Domingo, J.L., Falcó, G., Llobet, J.M., 2007. Concentrations of PCDD/PCDFs and PCBs in fish and seafood from the Catalan (Spain) market: Estimated human intake. Environment International 33, 170-175. doi:10.1016/j.envint.2006.09.005

Bodiguel, X., Loizeau, V., Le Guellec, A.-M., Roupsard, F., Philippon, X., Mellon-Duval, C., 2009a. Influence of sex, maturity and reproduction on PCB and p,p'DDE concentrations and repartitions in the European hake (Merluccius merluccius, L.) from the Gulf of Lions (N.W. Mediterranean). Science of the Total Environment 408, 304311. doi:10.1016/j.scitotenv.2009.10.004

Bodiguel, X., Maury, O., Mellon-Duval, C., Roupsard, F., Le Guellec, A.-M., Loizeau, V., 2009b. A dynamic and mechanistic model of PCB bioaccumulation in the European hake (Merluccius merluccius). Journal of Sea Research 62, 124-134.

Bodiguel, X., Tronczyński, J., Loizeau, V., Munschy, C., Guiot, N., Le Guellec, A., et al., 2008. Classical and novel organohalogen compounds (PCBs and PBDEs) in hake (M. merluccius, L.) from Mediterranean and Atlantic coasts (France). Environmental Toxicology 23, 157-167.

Borgå, K., Gabrielsen, G., Skaare, J., 2001. Biomagnification of organochlorines along a Barents Sea food chain. Environmental Pollution 113, 187-198.

Brown, T.M., Iverson, S.J., Fisk, A.T., Macdonald, R.W., Helbing, C.C., Reimer, K.J., 2015. Local contamination, and not feeding preferences, explains elevated PCB concentrations in Labrador ringed seals (Pusa hispida). Science of The Total Environment 515-516, 188-197. doi:10.1016/j.scitotenv.2015.02.019

Carravieri, A., Bustamante, P., Tartu, S., Meillère, A., Labadie, P., Budzinski, H., et al. 2014. Wandering Albatrosses Document Latitudinal Variations in the Transfer of Persistent Organic Pollutants and Mercury to Southern Ocean Predators. Environ. Sci. Technol. 48, 14746-14755. doi:10.1021/es504601m

Chessel, D., Dufour, A., Thioulouse, J., 2004. The ade4 package-I- One-table methods. R News 4, 5-10. 
Chouvelon, T., Caurant, F., Cherel, Y., Simon-Bouhet, B., Spitz, J., Bustamante, P., 2014. Species-and size-related patterns in stable isotopes and mercury concentrations in fish help refine marine ecosystem indicators and provide evidence for distinct management units for hake in the Northeast Atlantic. ICES Journal of Marine Science: Journal du Conseil 71, 1073-1087.

Choy, C.A., Popp, B.N., Kaneko, J., Drazen, J.C., 2009. The influence of depth on mercury levels in pelagic fishes and their preys. Proceedings of the National Academy of Sciences 106, 13865-13869.

Clarke, K., Warwick, R., 2001. Change in Marine Communities: An approach to statistical analysis and interpretation, 2nd edition. PRIMER-E: Plymouth.

Cossa, D., Averty, B., Pirrone, N., 2009. The origin of methylmercury in open Mediterranean waters. Limnology and Oceanography 54, 837-844.

Cossa, D., Buscail, R., Puig, P., Chiffoleau, J., Radakovitch, O., Jeanty, G., Heussner, S., 2014. Origin and accumulation of trace elements in sediments of the northwestern Mediterranean margin. Chemical Geology 380, 61-73.

Cossa, D., Coquery, M., 2005. The Mediterranean mercury anomaly, a geochemical or a biologocal issue., in: Saliot, A. (Ed.), The Mediterranean Sea. Handbook of Environmental Chemistry. Springer, pp. 177-208.

Cossa, D., Harmelin-Vivien, M., Mellon-Duval, C., Loizeau, V., Averty, B., Crochet, S., et al., 2012. Influence of bioavailability, trophic position, and growth on methylmercury in hakes (Merluccius merluccius) from Northwestern Mediterranean and Northeast Atlantic. Environmental Science and Technology 46, 4885-4893.

Cresson, P., Bouchoucha, M., Miralles, F., Ellebode, R., Mahé, K., Maruszcak, N., Thebault, H., Cossa, D. et al., 2015. Are red mullets efficient as bio-indicators of mercury contamination? A case study from the French Mediterranean. Marine Pollution Bulletin 91, 191-199. doi:http://dx.doi.org/10.1016/j.marpolbul.2014.12.005

Cresson, P., Fabri, M.C., Bouchoucha, M., Brach-Papa, C., Chavanon, F., Jadaud, A., et al. , 2014. Hg in organisms from the Northwestern Mediterranean slope: importance of the food sources. Science of The Total Environment 497-498, 229-238. doi:10.1016/j.scitotenv.2014.07.069

Cresson, P., Ruitton, S., Fontaine, M.-F., Harmelin-Vivien, M., 2012. Spatio-temporal variation of suspended and sedimentary organic matter quality in the Bay of Marseilles (NW Mediterranean) assessed by biochemical and isotopic analyses. Marine Pollution Bulletin 64, 1112-1121. doi:10.1016/j.marpolbul.2012.04.003

Darnaude, A.M., Salen-Picard, C., Polunin, N.V.C., Harmelin-Vivien, M., 2004. Trophodynamic linkage between river runoff and coastal fishery yield elucidated by stable isotope data in the Gulf of Lions (NW Mediterranean). Oecologia 138, 325332.

De Pontual, H., Groison, A.L., Piñeiro, C., Bertignac, M., 2006. Evidence of underestimation of European hake growth in the Bay of Biscay, and its relationship with bias in the agreed method of age estimation. ICES Journal of Marine Science: Journal du Conseil 63, 1674-1681. doi:10.1016/j.icesjms.2006.07.007

Dierking, J., Wafo, E., Schembri, T., Lagadec, V., Nicolas, C., Letourneur, Y., HarmelinVivien, M., 2009. Spatial patterns in PCBs, pesticides, mercury and cadmium in the common sole in the NW Mediterranean, and a novel use of contaminants as a biomarker. Marine Pollution Bulletin 58, 1605-1614.

Drazen, J.C., Haedrich, R.L., 2012. A continuum of life histories in deep-sea demersal fishes. Deep Sea Research Part I: Oceanographic Research Papers 61, 34-42.

Druon, J.-N., Fiorentino, F., Murenu, M., Knittweis, L., Colloca, F., Osio, C., et al. 2015. Modelling of European hake nurseries in the Mediterranean Sea: An ecological niche approach. Progress in Oceanography 130, 188-204. doi:10.1016/j.pocean.2014.11.005

Durrieu de Madron, X., Guieu, C., Sempéré, R., Conan, P., Cossa, D., D’Ortenzio, F. et al 2011. Marine ecosystems' responses to climatic and anthropogenic forcings in the 
Mediterranean. Progress in Oceanography 91, 97-166. doi:10.1016/j.pocean.2011.02.003

Endo, T., Hayasaka, M., Hisamichi, Y., Kimura, O., Haraguchi, K., 2013. Carbon and nitrogen stable isotope ratios and mercury concentration in the scalp hair of residents from Taiji, a whaling town. Marine Pollution Bulletin 69, 116-121. doi:10.1016/j.marpolbul.2013.01.018

Ferraton, F., Harmelin-Vivien, M., Mellon-Duval, C., Souplet, A., 2007. Spatio-temporal variation in diet may affect condition and abundance of juvenile European hake in the Gulf of Lions (NW Mediterranean). Marine Ecology-Progress Series 397, 197-208.

Fisk, A.T., Hobson, K.A., Norstrom, R.J., 2001. Influence of chemical and biological factors on trophic transfer of persistent organic pollutants in the Northwater Polynya marine food web. Environmental Science \& Technology 35, 732-738.

Fisk, A.T., Tittlemier, S.A., Pranschke, J.L., Norstrom, R.J., 2002. Using anthropogenic contaminants and stable isotopes to assess the feeding ecology of Greenland sharks. Ecology 83, 2162-2172.

Fitzgerald, W.F., Clarkson, T.W., 1991. Mercury and monomethylmercury: present and future concerns. Environmental Health Perspectives 96, 159-166.

Fleeger, J.W., Carman, K.R., Nisbet, R.M., 2003. Indirect effects of contaminants in aquatic ecosystems. Science of The Total Environment 317, 207-233.

Gagliano, M., McCormick, M.I., 2004. Feeding history influences otolith shape in tropical fish. Marine Ecology Progress Series 278, 291-296.

Galgani, F., Chiffoleau, J.-F., Orsoni, V., Costantini, L., Boissery, P., Calendini, S., Andral, B., 2006. Chemical contamination and sediment toxicity along the coast of Corsica. Chemistry and Ecology 22, 299-312.

Garrido, M., Koeck, B., Goffart, A., Collignon, A., Hecq, J.-H., Agostini, S., et al., 2014. Contrasting Patterns of Phytoplankton Assemblages in Two Coastal Ecosystems in Relation to Environmental Factors (Corsica, NW Mediterranean Sea). Diversity 6, 296-322.

GFCM, 2014. Report of the working group on stock assessment of demersal species (WGSAD). Rome, Italy.

Hall, B.D., Bodaly, R.A., Fudge, R.J.P., Rudd, J.W.M., Rosenberg, D.M., 1997. Food as the Dominant Pathway of Methylmercury Uptake by Fish. Water, Air, \& Soil Pollution 100, 13-24. doi:10.1023/a:1018071406537

Halpern, B.S., Walbridge, S., Selkoe, K.A., Kappel, C.V., Micheli, F., D’Agrosa, C., et al., 2008. A Global Map of Human Impact on Marine Ecosystems. Science 319, 948-952. doi:10.1126/science.1149345

Harmelin-Vivien, M., Bodiguel, X., Charmasson, S., Loizeau, V., Mellon-Duval, C., Tronczyński, J., Cossa, D., 2012a. Differential biomagnification of PCB, PBDE, Hg and Radiocesium in the food web of the European hake from the NW Mediterranean. Marine Pollution Bulletin 64, 974-983.

Harmelin-Vivien, M., Cossa, D., Crochet, S., Bănaru, D., Letourneur, Y., Mellon-Duval, C., 2009. Difference of mercury bioaccumulation in red mullets from the north-western Mediterranean and Black seas. Marine Pollution Bulletin 58, 679-685.

Harmelin-Vivien, M., Dierking, J., Bănaru, D., Fontaine, M.-F., Arlhac, D., 2010. Seasonal variation in stable $\mathrm{C}$ and $\mathrm{N}$ isotope ratios of the Rhone River inputs to the Mediterranean Sea (2004-2005). Biogeochemistry 100, 139-150.

Harmelin-Vivien, M., Mahé, K., Bodiguel, X., Mellon-Duval, C., 2012b. Possible link between prey quality, condition and growth of juvenile hake (Merluccius merluccius) in the Gulf of Lions (NW Mediterranean). Cybium 36, 323-328.

Heimbürger, L.E., Cossa, D., Marty, J.C., Migon, C., Averty, B., Dufour, A., Ras, J., 2010. Methyl mercury distribution in relation to the presence of nano- and picophytoplankton in an oceanic water column (Ligurian Sea, North-western Mediterranean). Geochemica et Cosmochimica Acta 74, 5549-5559. 
Hoekstra, P., O'hara, T., Fisk, A., Borgå, K., Solomon, K.R., Muir, D., 2003. Trophic transfer of persistent organochlorine contaminants (OCs) within an Arctic marine food web from the southern Beaufort-Chukchi Seas. Environmental Pollution 124, 509-522.

Kim, J.-H., Ludwig, W., Schouten, S., Kerhervé, P., Herfort, L., Bonnin, J., Sinninghe Damsté, J.S., 2007. Impact of flood events on the transport of terrestrial organic matter to the ocean: A study of the Têt River (SW France) using the BIT index. Organic Geochemistry 38, 1593-1606. doi:10.1016/j.orggeochem.2007.06.010

Lamborg, C.H., Hammerschmidt, C.R., Bowman, K.L., Swarr, G.J., Munson, K.M., Ohnemus, D.C., et al 2014. A global ocean inventory of anthropogenic mercury based on water column measurements. Nature 512, 65-68. doi:10.1038/nature13563

Lavoie, R.A., Kyser, T.K., Friesen, V.L., Campbell, L.M., 2015. Tracking Overwintering Areas of Fish-Eating Birds to Identify Mercury Exposure. Environ. Sci. Technol. 49, 863872. doi:10.1021/es502813t

Le Cren, E.D., 1951. The length-weight relationship and seasonal cycle in gonad weight and condition in the perch (Perca fluviatilis). The Journal of Animal Ecology 20, 201-219.

Lombarte, A., Lleonart, J., 1993. Otolith size changes related with body growth, habitat depth and temperature. Environmental Biology of Fishes 37, 297-306. doi:10.1007/BF00004637

Loonen, H., Van de Guchte, C., Parsons, J., De Voogt, P., Govers, H., 1996. Ecological hazard assessment of dioxins: hazards to organisms at different levels of aquatic food webs (fish-eating birds and mammals, fish and invertebrates). Science of The Total Environment 182, 93-103.

Maynou, F., Lleonart, J., Cartes, J., 2003. Seasonal and spatial variability of hake (Merluccius merluccius L.) recruitment in the NW Mediterranean. Fisheries Research $60,65-78$.

McMeans, B.C., Arts, M.T., Fisk, A.T., 2014. Impacts of food web structure and feeding behavior on mercury exposure in Greenland Sharks (Somniosus microcephalus). Science of The Total Environment 509-510, 216-225.

Mellon-Duval, C., de Pontual, H., Métral, L., Quemener, L., 2010. Growth of European hake (Merluccius merluccius) in the Gulf of Lions based on conventional tagging. ICES Journal of Marine Science 67, 62-70. doi:10.1093/icesjms/fsp215

Mérigot, B., Letourneur, Y., Lecomte-Finiger, R., 2007. Characterization of local populations of the common sole Solea solea (Pisces, Soleidae) in the NW Mediterranean through otolith morphometrics and shape analysis. Marine Biology 151, 997-1008. doi:10.1007/s00227-006-0549-0

Miralles, J., Arnaud, M., Radakovitch, O., Marion, C., Cagnat, X., 2006. Radionuclide deposition in the Rhône River Prodelta (NW Mediterranean sea) in response to the December 2003 extreme flood. Marine Geology 234, 179-189. doi:10.1016/j.margeo.2006.09.004

Morat, F., Lecomte-Finiger, R., Blamart, D., Robert, M., Letourneur, Y., 2012a. Preliminary indication of ontogenetic and spatial variations in the whole otolith isotopic and elemental signatures of Solea solea in the Gulf of Lions (NW Mediterranean). Scientia Marina 76, 647-657.

Morat, F., Letourneur, Y., Dierking, J., Pécheyran, C., Bareille, G., Blamart, D., HarmelinVivien, M., 2014. The Great Melting Pot. Common Sole Population Connectivity Assessed by Otolith and Water Fingerprints. Plos One 9, e86585. doi:10.1371/journal.pone.0086585

Morat, F., Letourneur, Y., Nerini, D., Banaru, D., Batjakas, I.E., 2012b. Discrimination of red mullet populations (Teleostean, Mullidae) along multi-spatial and ontogenetic scales within the Mediterranean basin on the basis of otolith shape analysis. Aquatic Living Resources 25, 27-39. doi:10.1051/alr/2011151

Mourier, B., Desmet, M., Van Metre, P.C., Mahler, B.J., Perrodin, Y., Roux, G., et al., 2014. Historical records, sources, and spatial trends of PCBs along the Rhône River (France). Science of The Total Environment 476-477, 568-576. doi:10.1016/j.scitotenv.2014.01.026 
Mulder, T., Syvitski, J.P.M., Migeon, S., Faugères, J.-C., Savoye, B., 2003. Marine hyperpycnal flows: initiation, behavior and related deposits. A review. Marine and Petroleum Geology 20, 861-882. doi:10.1016/j.marpetgeo.2003.01.003

Nakhlé, K., Cossa, D., Claisse, D., Beliaeff, B., Simon, S., 2007. Cadmium and mercury in Seine Estuary flounders and muscle: the results of two decades of monitoring. ICES Journal of Marine Science 64, 929-938.

Nfon, E., Cousins, I.T., 2006. Interpreting time trends and biomagnification of PCBs in the Baltic region using the equilibrium lipid partitioning approach. Environmental pollution 144, 994-1000.

Pergent, G., Labbe, C., Lafabrie, C., Kantin, R., Pergent-Martini, C., 2011. Organic and inorganic human-induced contamination of Posidonia oceanica meadows. Ecological Engineering 37, 999-1002. doi:10.1016/j.ecoleng.2011.02.001

Pinnegar, J.K., Polunin, N.V.C., 1999. Differential fractionation of $\delta^{13} \mathrm{C}$ and $\delta^{15} \mathrm{~N}$ among fish tissues: implications for the study of trophic interactions. Functional Ecology 13, 225231. doi:DOI: 10.1046/j.1365-2435.1999.00301.x

Polunin, N.V.C., Morales-Nin, B., Pawsey, W., Cartes, J., Pinnegar, J., Moranta, J., 2001. Feeding relationships in Mediterranean bathyal assemblages elucidated by stable and nitrogen carbon isotope data. Marine Ecology Progress Series 220, 13-23.

Porte, C., Escartín, E., García de la Parra, L.M., Biosca, X., Albaigés, J., 2002. Assessment of coastal pollution by combined determination of chemical and biochemical markers in Mullus barbatus. Marine Ecology Progress Series 235, 205-216. doi:10.3354/meps235205

Radakovitch, O., Roussiez, V., Ollivier, P., Ludwig, W., Grenz, C., Probst, J.-L., 2008. Input of particulate heavy metals from rivers and associated sedimentary deposits on the Gulf of Lion continental shelf. Estuarine, Coastal and Shelf Science 77, 285-295. doi:10.1016/j.ecss.2007.09.028

Rau, G.H., Teyssie, J.L., Rassoulzadegan, F., Fowler, S.W., $1990 .{ }^{13} \mathrm{C} /{ }^{12} \mathrm{C}$ and ${ }^{15} \mathrm{~N} /{ }^{14} \mathrm{~N}$ variations among size-fractionated marine particles: implications for their origin and trophic relationships. Marine Ecology-Progress Series 59, 33-38.

$\mathrm{R}$ Core Team, 2014. R: A langage and environment for statistical computing. $\mathrm{R}$ foundation for Statistical computing, Vienna, Austria.

Recasens, L., Lombarte, A., Morales-Nin, B., Tores, G., 1998. Spatiotemporal variation in the population structure of the European hake in the NW Mediterranean. Journal of Fish Biology 53, 87-401.

Salen-Picard, C., Darnaude, A.M., Arlhac, D., Harmelin-Vivien, M.L., 2002. Fluctuations of macrobenthic populations: a link between climate-driven river run-off and sole fishery yields in the Gulf of Lions. Oecologia 133, 380-388.

Serrano, O., Martínez-Cortizas, A., Mateo, M.A., Biester, H., Bindler, R., 2013. Millennial scale impact on the marine biogeochemical cycle of mercury from early mining on the Iberian Peninsula. Global Biogeochemical Cycles 27, 21-30. doi:10.1029/2012gb004296

Sinopoli, M., Fanelli, E., D'Anna, G., Badalamenti, F., Pipitone, C., 2012. Assessing the effects of a trawling ban on diet and trophic level of hake, Merluccius merluccius, in the southern Tyrrhenian Sea. Scientia Marina 76, 677-690.

Storelli, M.M., 2008. Potential human health risks from metals $(\mathrm{Hg}, \mathrm{Cd}$, and $\mathrm{Pb}$ ) and polychlorinated biphenyls (PCBs) via seafood consumption: Estimation of target hazard quotients (THQs) and toxic equivalents (TEQs). Food and Chemical Toxicology 46, 2782-2788. doi:10.1016/j.fct.2008.05.011

Storelli, M.M., Barone, G., 2013. Toxic Metals (Hg, Pb, and Cd) in Commercially Important Demersal Fish from Mediterranean Sea: Contamination Levels and Dietary Exposure Assessment. Journal of Food Science 78, T362-T366. doi:10.1111/j.17503841.2012.02976.x

Storelli, M.M., Storelli, A., Giacominelli-Stuffler, R., Marcotrigiano, G.., 2005. Mercury speciation in the muscle of two commercially important fish, hake (Merluccius 
merluccius) and striped mullet (Mullus barbatus) from the Mediterranean Sea: estimated weekly intake. Food Chemistry 89, 295-300.

Streets, D., Devane, M., Lu, Z., Bond, T., Sunderland, E., Jacob, D., 2011. All-Time Releases of Mercury to the Atmosphere from Human Activities. Environmental Science and Technology 45, $10485-10491$.

Sweeting, C.J., Polunin, N.V.C., Jennings, S., 2006. Effects of chemical lipid extraction and arithmetic lipid correction on stable isotope ratios of fish tissues. Rapid Communications in Mass Spectrometry 20, 595-601.

Tartu, S., Goutte, A., Bustamante, P., Angelier, F., Moe, B., Clément-Chastel, C., et al. 2013. To breed or not to breed: endocrine response to mercury contamination by an Arctic seabird. Biology Letters 9, 20130317.

UNEP, 2013. Global mercury assessment 2013: Sources, emissions, releases and environmental transport. Geneva, Switzerland. 


\section{Tables}

Tab. 1: Hake biometry, regarding origin and sex. Kr: Le Cren condition factor. Results of the statistical comparison tests are provided in Table S1.

\begin{tabular}{|c|c|c|c|c|c|c|c|c|c|c|c|c|}
\hline \multirow[t]{2}{*}{ Origin } & \multirow[t]{2}{*}{ Sex } & \multirow[t]{2}{*}{$\mathrm{n}$} & \multicolumn{2}{|c|}{$\begin{array}{l}\text { Total length } \\
(\mathrm{mm})\end{array}$} & \multicolumn{2}{|c|}{ Age (a) } & \multicolumn{2}{|c|}{ Total mass (g) } & \multicolumn{2}{|c|}{$\mathrm{Kr}$} & \multicolumn{2}{|c|}{$\mathrm{C} / \mathrm{N}$} \\
\hline & & & Mean & $\mathrm{sd}$ & Mean & $\mathrm{sd}$ & Mean & sd & Mean & sd & Mean & sd \\
\hline \multirow[t]{3}{*}{ Bastia } & Female & 41 & 297 & 70 & 1.5 & 0.4 & 207.01 & 152.29 & 0.82 & 0.07 & 3.15 & 0.03 \\
\hline & Male & 22 & 297 & 53 & 2.3 & 0.6 & 192.61 & 122.66 & 0.82 & 0.08 & 3.15 & 0.06 \\
\hline & Juvenile & 22 & 179 & 33 & 1.0 & 0.2 & 38.42 & 28.84 & 0.87 & 0.10 & 3.15 & 0.03 \\
\hline \multirow[t]{3}{*}{ Le Grau du Roi } & Female & 35 & 337 & 64 & 1.8 & 0.4 & 355.08 & 190.70 & 0.94 & 0.11 & 3.18 & 0.06 \\
\hline & Male & 14 & 254 & 60 & 1.9 & 0.6 & 148.03 & 111.43 & 1.03 & 0.11 & 3.28 & 0.12 \\
\hline & Juvenile & 20 & 172 & 27 & 1.0 & 0.2 & 41.23 & 24.37 & 1.08 & 0.07 & 3.29 & 0.15 \\
\hline \multirow[t]{3}{*}{ Port la Nouvelle } & Female & 35 & 315 & 51 & 1.6 & 0.3 & 269.97 & 145.12 & 0.92 & 0.06 & 3.19 & 0.07 \\
\hline & Male & 17 & 298 & 30 & 2.3 & 0.3 & 193.58 & 52.52 & 0.88 & 0.08 & 3.17 & 0.06 \\
\hline & Juvenile & 18 & 185 & 24 & 1.0 & 0.2 & 46.16 & 19.70 & 1.01 & 0.05 & 3.17 & 0.03 \\
\hline
\end{tabular}


Table 2: PCB contamination patterns regarding sampling site and sex. CB 153: mean, standard deviation, minimum and maximum concentration, expressed in $\mathrm{ng} \mathrm{g}^{-1}$ dry mass. $\Sigma$ : sum of congeners $28,52,101,118,138,153,180$ (ICES indicator PCBs). Adjacent columns present the mean and standard deviation of the percentage of each PCB class, depending on the chlorination number. < DL: below detection limits.

\begin{tabular}{|c|c|c|c|c|c|c|c|c|c|c|c|c|c|c|c|c|}
\hline \multirow[b]{2}{*}{ Origin } & \multirow[b]{2}{*}{ Sex } & \multicolumn{4}{|c|}{ CB $153\left(\mathrm{ng} \mathrm{g}^{-1} \mathrm{dm}\right)$} & \multicolumn{2}{|c|}{$\Sigma 7\left(\mathrm{ng} \mathrm{g}^{-1} \mathrm{dm}\right)$} & \multirow{2}{*}{$\begin{array}{c}3 \mathrm{Cl} \\
(\mathrm{CB} 28) \\
\text { Mean } \\
\end{array}$} & \multicolumn{2}{|c|}{$\begin{array}{c}4 \mathrm{Cl} \\
(\mathrm{CB} 52)\end{array}$} & \multicolumn{2}{|c|}{$\begin{array}{c}5 \mathrm{Cl}(\mathrm{CB} \mathrm{101}, \\
105,118)\end{array}$} & \multicolumn{2}{|c|}{$\begin{array}{c}6 \mathrm{Cl}(\mathrm{CB} 138 \\
153,156)\end{array}$} & \multicolumn{2}{|c|}{$\begin{array}{c}7 \mathrm{Cl} \\
\text { (CB 180) }\end{array}$} \\
\hline & & Mean & sd & Min & Max & Mean & sd & & Mean & sd & Mean & $\mathrm{sd}$ & Mean & $\mathrm{sd}$ & Mean & sd \\
\hline \multirow{3}{*}{ Bastia } & Female & 4.80 & 6.09 & 1.23 & 34.95 & 11.89 & 14.22 & $<D L$ & $1 \%$ & $1 \%$ & $17 \%$ & $3 \%$ & $65 \%$ & $2 \%$ & $18 \%$ & $3 \%$ \\
\hline & Male & 6.75 & 4.22 & 1.89 & 16.99 & 17.19 & 10.33 & $<\mathrm{DL}$ & $1 \%$ & $1 \%$ & $18 \%$ & $2 \%$ & $64 \%$ & $2 \%$ & $18 \%$ & $2 \%$ \\
\hline & Juvenile & 4.15 & 2.25 & 2.03 & 7.70 & 11.26 & 5.86 & $<\mathrm{DL}$ & $1 \%$ & $1 \%$ & $19 \%$ & $2 \%$ & $62 \%$ & $2 \%$ & $18 \%$ & $2 \%$ \\
\hline \multirow{3}{*}{$\begin{array}{c}\text { Le Grau du } \\
\text { Roi }\end{array}$} & Female & 12.96 & 9.69 & 3.03 & 37.31 & 28.32 & 21.81 & $<\mathrm{DL}$ & $1 \%$ & $0 \%$ & $12 \%$ & $2 \%$ & $68 \%$ & $2 \%$ & $18 \%$ & $4 \%$ \\
\hline & Male & 6.68 & 5.17 & 3.33 & 21.29 & 14.53 & 10.90 & $<\mathrm{DL}$ & $2 \%$ & $1 \%$ & $15 \%$ & $2 \%$ & $68 \%$ & $2 \%$ & $16 \%$ & $2 \%$ \\
\hline & Juvenile & 8.07 & 4.28 & 4.75 & 19.07 & 17.92 & 9.22 & $<\mathrm{DL}$ & $2 \%$ & $0 \%$ & $15 \%$ & $1 \%$ & $67 \%$ & $1 \%$ & $16 \%$ & $1 \%$ \\
\hline \multirow{3}{*}{$\begin{array}{l}\text { Port La } \\
\text { Nouvelle }\end{array}$} & Female & 7.05 & 4.89 & 2.04 & 24.22 & 15.83 & 10.47 & $<\mathrm{DL}$ & $1 \%$ & $1 \%$ & $13 \%$ & $2 \%$ & $68 \%$ & $2 \%$ & $19 \%$ & $2 \%$ \\
\hline & Male & 18.39 & 12.38 & 3.78 & 47.96 & 40.34 & 26.30 & $<D L$ & $1 \%$ & $0 \%$ & $11 \%$ & $2 \%$ & $69 \%$ & $1 \%$ & $19 \%$ & $2 \%$ \\
\hline & Juvenile & 4.00 & 0.64 & 3.22 & 5.39 & 9.87 & 1.86 & $<\mathrm{DL}$ & $2 \%$ & $0 \%$ & $17 \%$ & $1 \%$ & $65 \%$ & $1 \%$ & $16 \%$ & $2 \%$ \\
\hline
\end{tabular}


Table 3: Temporal change of CB 153 concentration in hake in the Gulf of Lions, depending on the size class between $2004-2006$ (HarmelinVivien et al., 2012a) and 2013 (present study). Concentrations measured at Bastia were not taken into consideration here. For the $50-74 \mathrm{~cm}$ size-class, value for 2013 results from one single large individual, not considered elsewhere in the paper. Age range was calculated on the basis of the parameters of the age-length relationship calculated in the Gulf of Lions by Mellon-Duval et al. (2010), considering juveniles, females and males together.

\begin{tabular}{ccccccc}
\hline \multirow{2}{*}{ Size-class $(\mathrm{cm})$} & Calculated age & \multicolumn{2}{c}{$2004-2006$} & \multicolumn{2}{c}{2013} & Change \\
& & $\mathrm{n}$ & Mean $\pm \mathrm{sd}$ & $\mathrm{n}$ & mean & \\
\hline $15-24$ & $0.7-1.7$ & 80 & $27.4 \pm 9.6$ & 46 & $6.1 \pm 3.5$ & $-78 \%$ \\
$25-39$ & $1.2-3.3$ & 176 & $56.1 \pm 42.1$ & 82 & $11.0 \pm 9.4$ & $-80 \%$ \\
$40-49$ & $2.1-4.8$ & 57 & $51.1 \pm 21.4$ & 11 & $17.0 \pm 12.5$ & $-77 \%$ \\
$50-74$ & $2.9-5.6$ & 14 & $59.5 \pm 47.9$ & 1 & 34.19 & $-43 \%$ \\
\hline
\end{tabular}




\section{Figures}

Fig. 1: Map of the sampling sites, with trawling trajectories represented by the hatched lines, and with rivers (Rhône and Golo rivers) or coastal lagoons (Bages Sigean, Leucate and Canet coastal lagoons) for which influence on juvenile hake is expected. For graphic purposes, isobaths are represented near the trawling locations only. GoL: Gulf of Lions.

Fig.2: Mean \pm sd isotopic ratios $\left(\delta^{13} \mathrm{C}\right.$ and $\delta^{15} \mathrm{~N}, \%$ ) in hake, depending on the sampling site (white plot with red border: Bastia, light grey with green border: Le Grau du Roi and dark grey with blue border: Port la Nouvelle) and of the sex of the individuals (circle: juveniles, square: females and triangle: males). For interpretation of color references in this figure legend, the reader is referred to the web version of this article.

Fig. 3: Total $\mathrm{Hg}$ (in $\mu \mathrm{g} \mathrm{g}^{-1}$ dry mass) or CB 153 (ng g ${ }^{-1}$ dry mass) at the three sites (white boxplot with red border: Bastia, light grey with green border: Le Grau du Roi and dark grey with blue border: Port la Nouvelle) for each $5 \mathrm{~cm}$ size class. Box hinges are the $1^{\text {st }}$ and $3^{\text {rd }}$ quartiles, line is the median value, and whiskers extend from the hinge to the highest or lowest value that is within $1.5 \times$ interquartile range. Points are outlier values. Shape of the curves represent the best fitting model; see Table S2 for the parameters of the regressions. For interpretation of the color references in this figure legend, the reader is referred to the web version of this article.

Fig. 4: First plan resulting from the CDA on $\delta^{13} \mathrm{C}$ and $\delta^{15} \mathrm{~N}$ ratios, log $\mathrm{Hg}$ and $\log \mathrm{CB} 153$ concentrations, and on the coordinates of the otolith shape in the first plan of the CDA on Fourier coefficients. Shape of the symbol refers to the sex (circles: juveniles; square: females, triangles: adults) and color to the origin (white symbol with red border: Bastia, grey symbol with green border: Le Grau du Roi, black symbol with blue border: Port la Nouvelle). Values represent the percentage of good-reclassification for each group. For graphic purposes, origins were abbreviated (GDR: Le Grau du Roi, PLN: Port la Nouvelle). Ellipses are $75 \%$ confidence ellipses, the color of which refers to the origin and line type refers to the sex (small dotted line: juveniles, large dotted line: females, solid line: males). Contribution of the variables to each axis is provided in the table in the upper right corner of the figure. For interpretation of the color references in this figure legend, the reader is referred to the web version of this article

Fig. 5: Daily flow of the Rhône River, during the 1995 - 2014 period. Arrows stand for the flooding events (discharge higher than $6000 \mathrm{~m}^{3} \mathrm{~s}^{-1}$ ). Sampling periods of the individuals compared in Table 3 are represented by the black squares above x-axis (2004-2006 for the data from Harmelin-Vivien et al. (2012a) and 2013 for results of the present study), with the grey zones standing for the expected lifespan of the largest individuals of each sampling, and calculated on the basis of the parameters determined by Mellon-Duval et al. (2010). Data are from the Beaucaire station, near the mouth of the river, and are courtesy of the Compagnie Nationale du Rhône. 
Fig. 1:

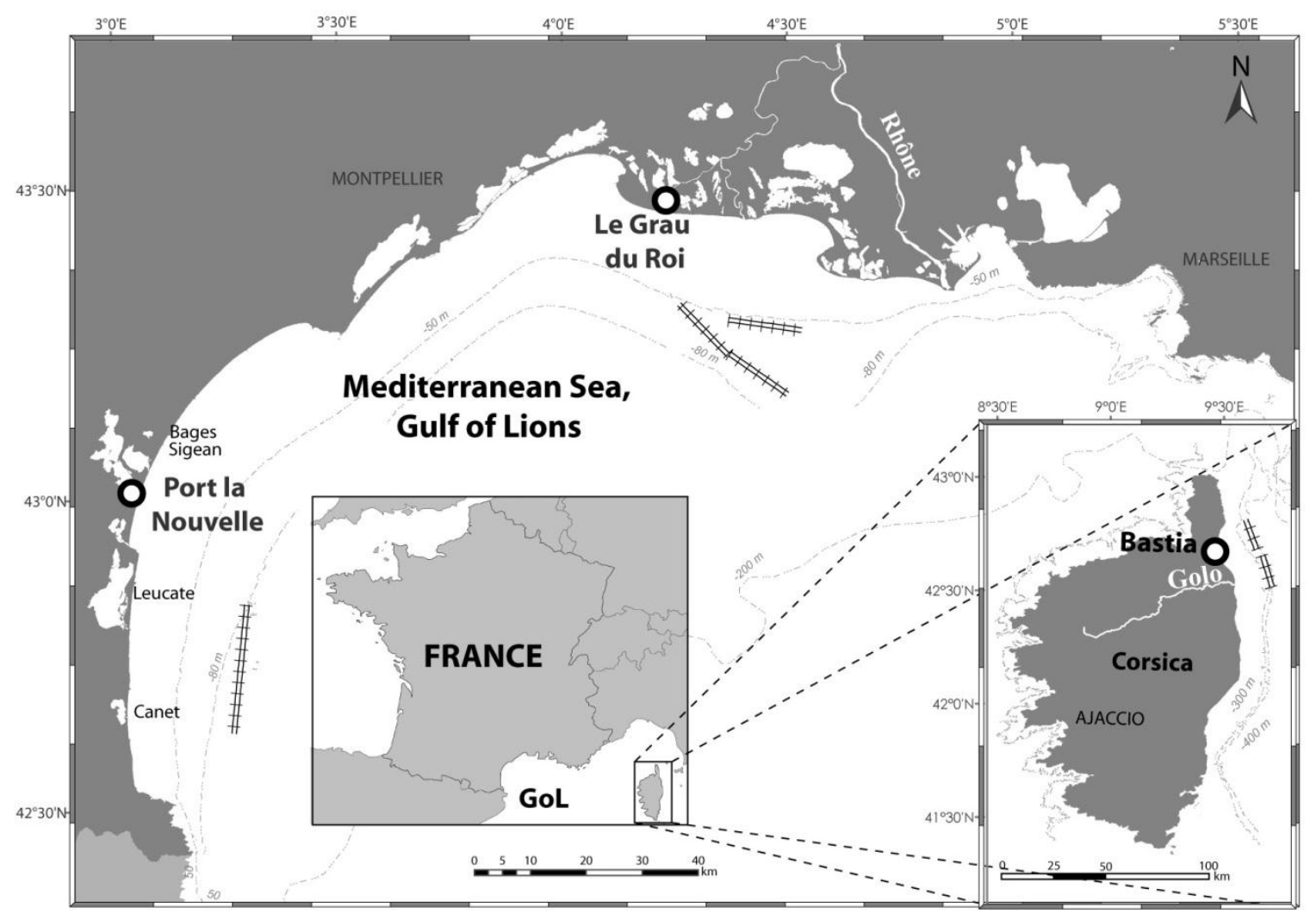


Fig. 2:

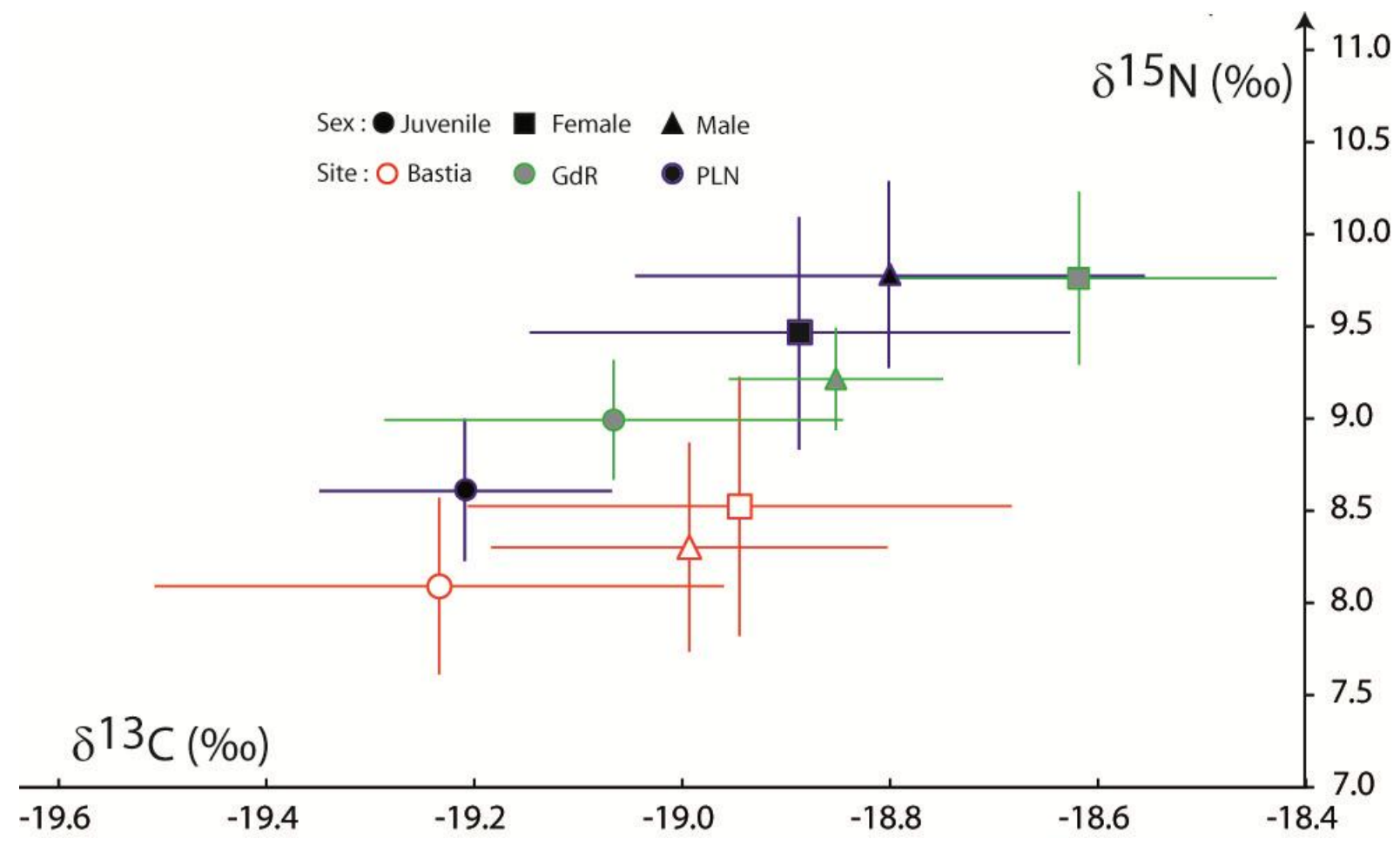


Fig. 3:
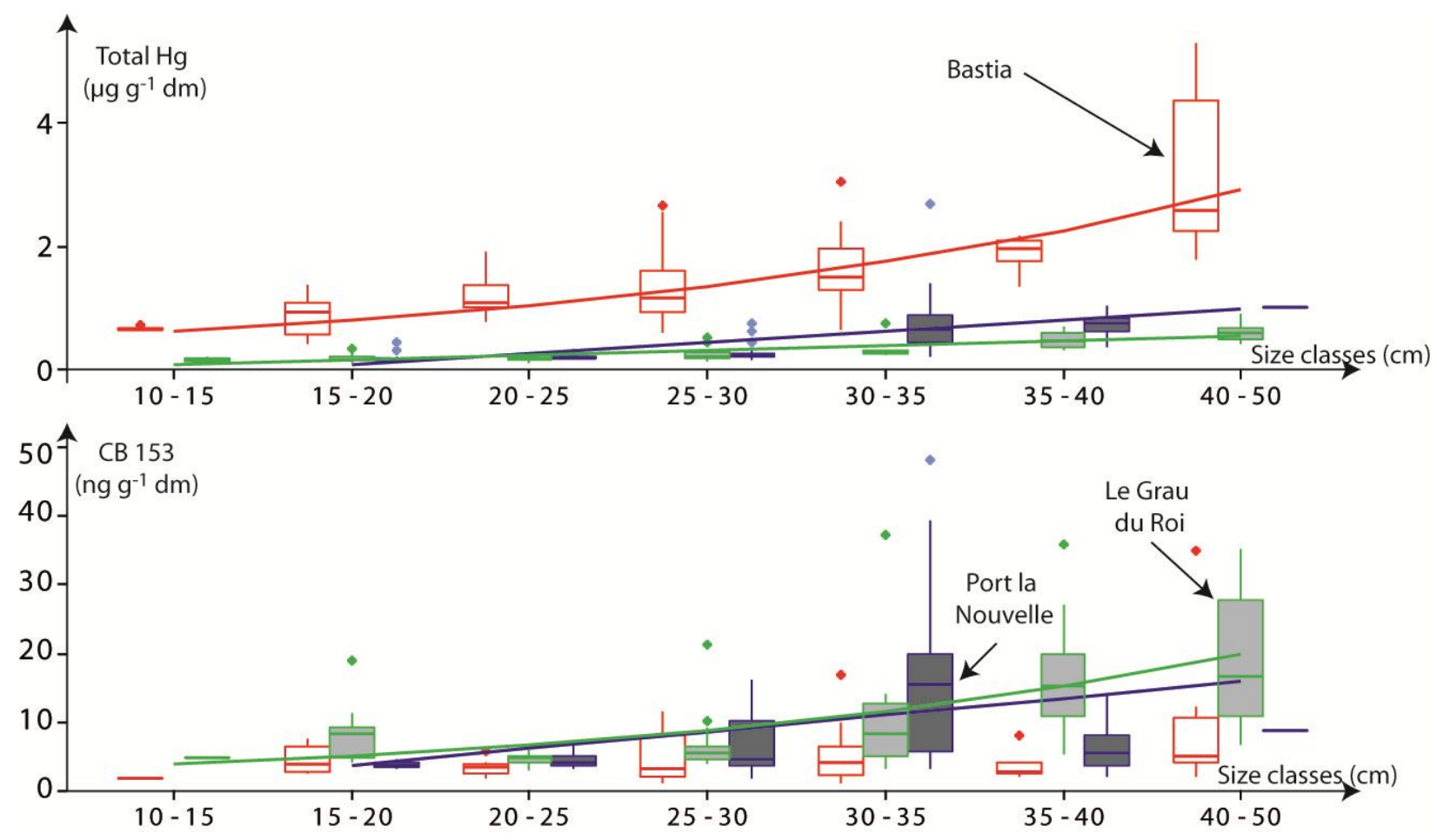
Fig. 4:

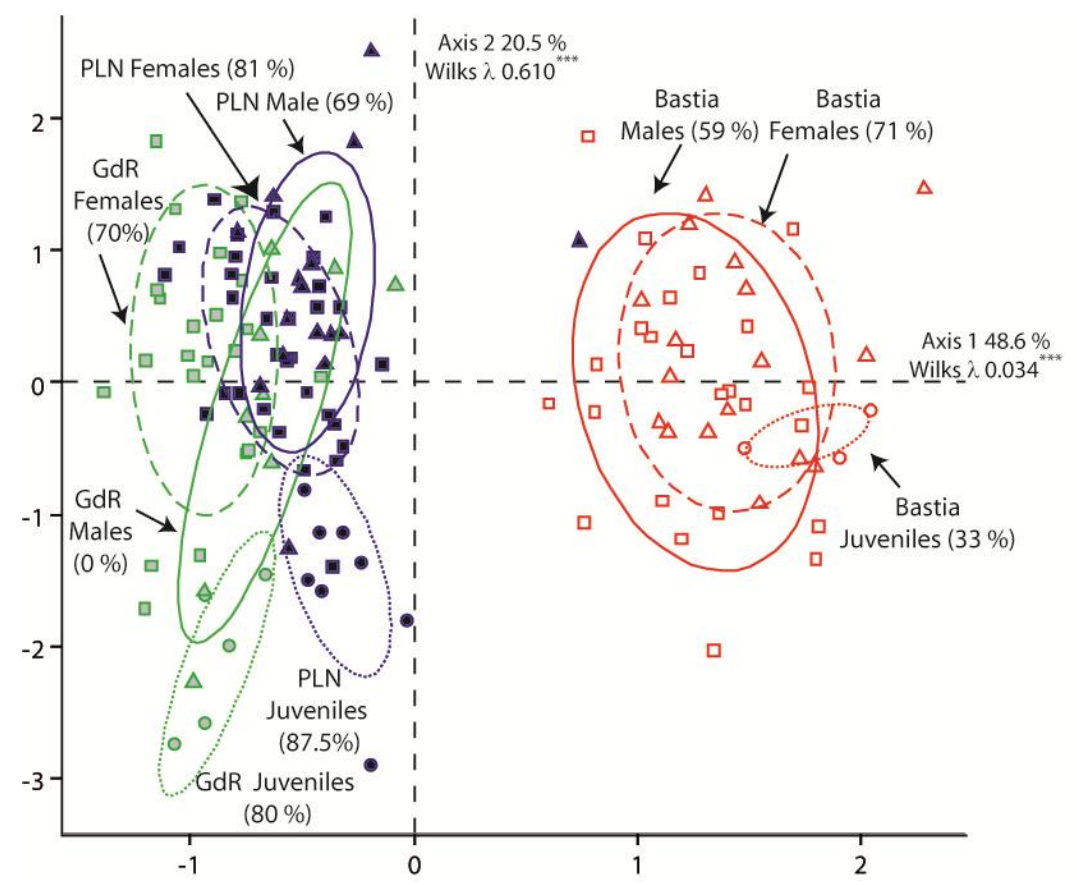

\begin{tabular}{lrr}
\hline & Axis 1 & Axis 2 \\
\hline $\log \mathrm{Hg}$ & 0.66 & 0.11 \\
$\log \mathrm{PCB} 153$ & -0.12 & 0.23 \\
$\delta^{13} \mathrm{C}$ & -0.01 & 0.29 \\
$\delta^{15} \mathrm{~N}$ & -0.44 & -0.02 \\
Otol 1 & 0.08 & -0.55 \\
Otol 2 & 0.10 & 0.72 \\
\hline
\end{tabular}

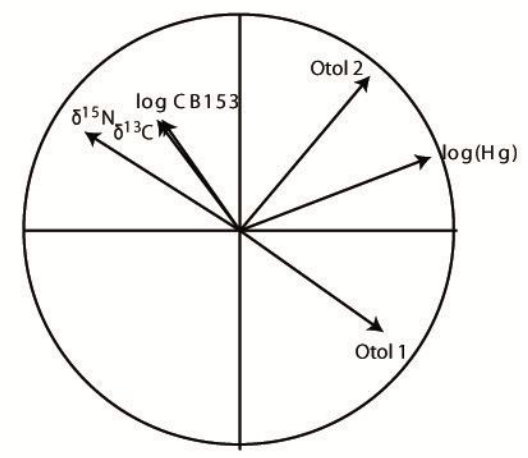


Fig. 5:

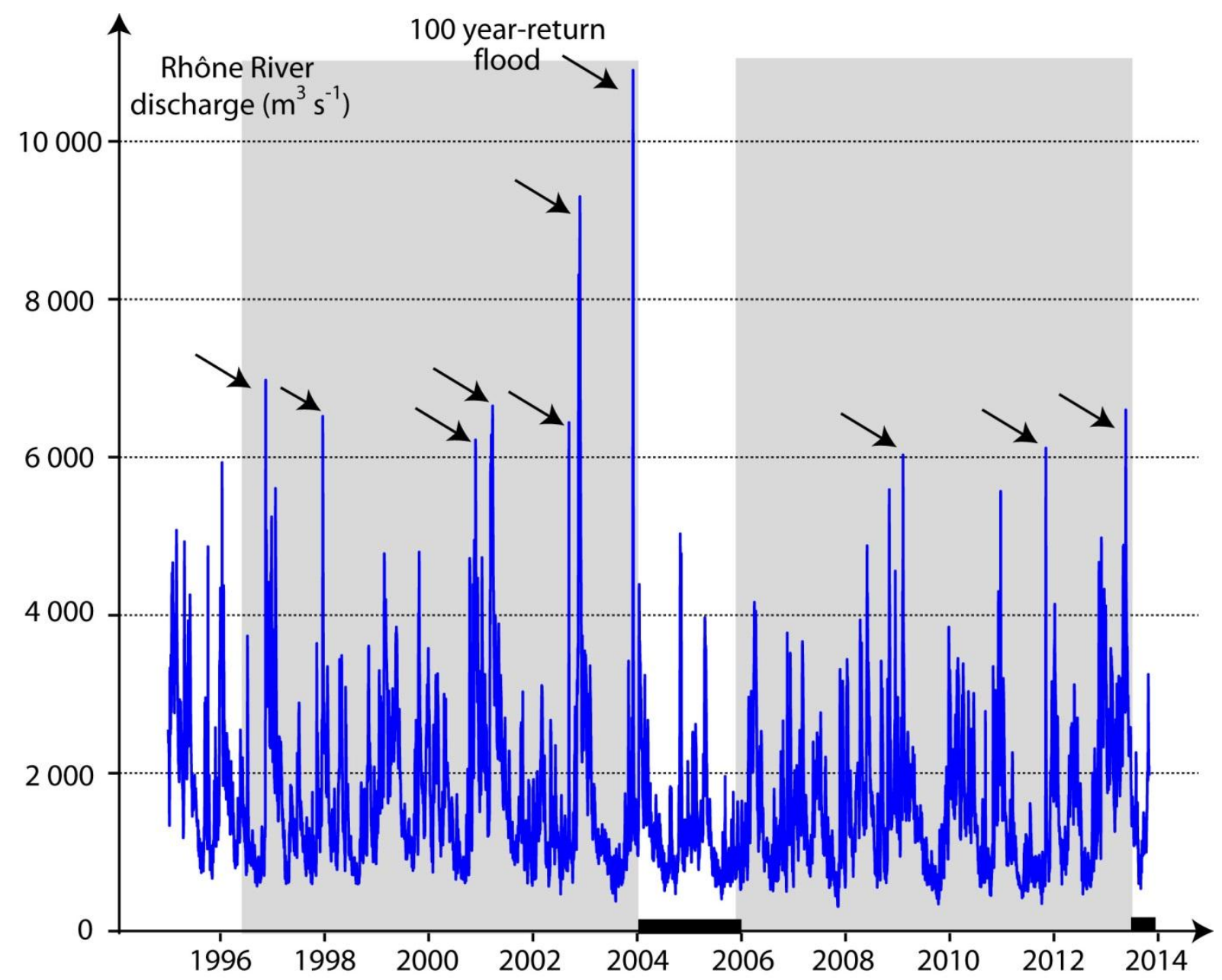


Table S1: Actual sampling size, depending on sites, size classes and sex. Results for the individual larger than $50 \mathrm{~cm}$ collected at le Grau du Roi were used for comparative purposes in Table 3 only but not for numerical analyses elsewhere in the paper.

\begin{tabular}{|c|c|c|c|c|c|c|c|c|c|}
\hline \multirow{2}{*}{ Sampling site } & \multirow{2}{*}{ Sex } & \multicolumn{8}{|c|}{ Size classes $(\mathrm{cm})$} \\
\hline & & $10-15$ & $15-20$ & $20-25$ & $25-30$ & $30-35$ & $35-40$ & $40-50$ & $>50$ \\
\hline \multirow[t]{3}{*}{ Bastia } & Female & & 3 & 6 & 13 & 11 & 3 & 5 & \\
\hline & Male & & & 5 & 7 & 8 & 1 & 1 & \\
\hline & Juvenile & 4 & 13 & 4 & 1 & & & & \\
\hline \multirow{3}{*}{ le Grau du Roi } & Female & & 1 & 2 & 8 & 8 & 9 & 7 & 1 \\
\hline & Male & & 3 & 4 & 5 & 1 & 1 & & \\
\hline & Juvenile & 4 & 13 & 2 & 1 & & & & \\
\hline \multirow[t]{3}{*}{ Port la Nouvelle } & Female & & & 1 & 16 & 9 & 8 & 1 & \\
\hline & Male & & & 1 & 5 & 11 & & & \\
\hline & Juvenile & & 10 & 8 & & & & & \\
\hline
\end{tabular}


Table S2: Permutation multivariate analysis of variance (PERMANOVA) for biometric, isotopic or contamination parameters. The sources of variance are origin (GdR: Grau du Roi; PLN: Port La Nouvelle; Bas: Bastia) or sex (Juv: Juvenile; Fem: Female, Male). Transformation and distance matrix used are detailed for each source

\begin{tabular}{|c|c|c|c|c|c|c|c|}
\hline Source of variance & & df & MS & Pseudo-F & $p$-value & \multicolumn{2}{|l|}{ pairwise tests } \\
\hline \multicolumn{8}{|l|}{ Biometric parameters } \\
\hline \multirow{4}{*}{$\begin{array}{c}\text { Total length } \\
\text { log }(X+1) \text { transf. } \\
\text { Euclidean distance }\end{array}$} & Origin & 2 & 0.07 & 2.16 & 0.1207 & & \\
\hline & Sex & 2 & 5.99 & 177.48 & 0.0001 & \multicolumn{2}{|l|}{ Juv $<$ Male $<$ Fem } \\
\hline & Origin $x$ Sex & 4 & 0.14 & 4.11 & 0.0029 & $\begin{array}{l}\text { Fem: Bas }=\text { PLN, GdR=PLN, Bas }<\text { GdR } \\
\text { Male: GdR }<\text { Bas }=\text { PLN } \\
\text { Juv: GdR }<\text { Bas }<\text { PLN }\end{array}$ & $\begin{array}{l}\text { Bas: Juv }<\text { Male }=\text { Fem } \\
\text { GdR: Juv }<\text { Male }<\text { Fem } \\
\text { PLN: Juv }<\text { Male }=\text { Fem }\end{array}$ \\
\hline & Residuals & 215 & 0.03 & & & & \\
\hline
\end{tabular}

\begin{tabular}{|c|c|c|c|c|c|l|l|}
\hline & Origin & 2 & 0.13 & 0.94 & 0.3973 & \\
\cline { 2 - 8 } $\begin{array}{c}\text { Age } \\
\begin{array}{c}\text { Untransformed } \\
\text { Euclidean distance }\end{array}\end{array}$ & Sex & 2 & 23.82 & 170.82 & 0.0001 & Juv < Fem < Male \\
\cline { 2 - 8 } & Origin $\times$ Sex & 4 & 0.66 & 4.75 & 0.0011 & $\begin{array}{l}\text { Fem: Bas < GdR, Bas = PLN, PLN = GdR, } \\
\text { Male: GdR < PLN, Bas = PLN, Bas = GdR } \\
\text { Juv: GdR = Bas = PLN }\end{array}$ & $\begin{array}{l}\text { Bas: Juv < Fem < Male } \\
\text { GdR: Juv < Fem = Male } \\
\text { PLN: Juv < Fem < Male }\end{array}$ \\
\cline { 2 - 8 } & Residuals & 215 & 0.14 & & & \\
\hline
\end{tabular}

\begin{tabular}{|c|c|c|c|c|c|l|l|}
\hline \multirow{4}{*}{$\begin{array}{c}\text { Kr } \\
\begin{array}{c}\text { Untransformed } \\
\text { Euclidean distance }\end{array}\end{array}$} & Origin & 2 & 0.24 & 37.04 & 0.0001 & Bas < PLN < GdR \\
\cline { 2 - 8 } & Origin $\times$ Sex & 4 & 0.02 & 2.75 & 0.0341 & $\begin{array}{l}\text { Fem: Bas < PLN = GdR } \\
\text { Male: Bas < PLN < GdR } \\
\text { Juv: Bas < PLN = GdR }\end{array}$ & $\begin{array}{l}\text { Bas: Male = Fem = Juv } \\
\text { GdR: Fem < Male = Juv } \\
\text { PLN: Male < Fem = Juv }\end{array}$ \\
\cline { 2 - 8 } & Residuals & 159 & 0.01 & & & & \\
\hline
\end{tabular}




\begin{tabular}{|c|c|c|c|c|c|c|c|}
\hline Isotopic parameters & & & & & & & \\
\hline \multirow{4}{*}{$\begin{array}{c}\delta^{13} \mathrm{C} \text { (no covariate) } \\
\text { Untransformed } \\
\text { Euclidean distance }\end{array}$} & Origin & 2 & 0.82 & 15.30 & 0.0001 & \multicolumn{2}{|l|}{ Bas $<\mathrm{PLN}<\mathrm{GdR}$} \\
\hline & Sex & 2 & 2.66 & 49.32 & 0.0001 & \multicolumn{2}{|l|}{ Juv $<$ Male $<$ Fem } \\
\hline & Origin $\times$ Sex & 4 & 0.14 & 2.57 & 0.0364 & $\begin{array}{l}\text { Fem: } \text { Bas }=\text { PLN }<\text { GdR } \\
\text { Male: } \text { Bas }<\text { GdR }=\text { PLN } \\
\text { Juv: } \text { Bas }=\text { PLN }<\text { GdR }\end{array}$ & $\begin{array}{l}\text { Bas: Juv }<\text { Male }=\text { Fem } \\
\text { GdR: Juv }<\text { Male }<\text { Fem } \\
\text { PLN: Juv }<\text { Fem = Male }\end{array}$ \\
\hline & Residuals & 214 & 0.05 & & & & \\
\hline \multirow{5}{*}{$\begin{array}{c}\delta^{13} \mathrm{C} \text { (Total length as } \\
\text { covariate) } \\
\text { Untransformed } \\
\text { Euclidean distance }\end{array}$} & Total length & 1 & 7.81 & 178.34 & 0.0001 & & \\
\hline & Origin & 2 & 1.05 & 24.04 & 0.0001 & \multicolumn{2}{|l|}{ Bas $<\mathrm{PLN}<\mathrm{GdR}$} \\
\hline & Sex & 2 & 0.08 & 1.87 & 0.1550 & \\
\hline & Origin $\times$ Sex & 4 & 0.05 & 1.25 & 0.2882 & \\
\hline & Residuals & 215 & 0.04 & & & \\
\hline \multirow{5}{*}{$\begin{array}{c}\delta^{15} \mathrm{~N} \text { (no covariate) } \\
\text { Untransformed } \\
\text { Euclidean distance }\end{array}$} & & & & & & \multirow{2}{*}{\multicolumn{2}{|c|}{ Bas $<\mathrm{PLN}<\mathrm{GdR}$}} \\
\hline & Origin & 2 & 24.56 & 84.31 & 0.0001 & & \\
\hline & Sex & 2 & 9.57 & 32.85 & 0.0001 & \multicolumn{2}{|l|}{ Juv $<$ Male $=$ Fem } \\
\hline & Origin $\times$ Sex & 4 & 1.68 & 5.77 & 0.0004 & \multirow{2}{*}{\multicolumn{2}{|c|}{$\begin{array}{l}\text { Fem: } \text { Bas }<\text { PLN }=\text { GdR } \\
\text { Male: } \text { Bas }<\text { GdR }<\text { PLN } \\
\text { Juv: } \text { Bas }<\text { PLN }<\text { GdR }\end{array}$}} \\
\hline & Res & 215 & 0.29 & & & & \\
\hline \multirow{5}{*}{$\begin{array}{c}\delta^{15} \mathbf{N} \text { (Total length as a } \\
\text { covariate) } \\
\text { Untransformed } \\
\text { Euclidean distance }\end{array}$} & Total length & 1 & 44.99 & 23294 & 00001 & & \\
\hline & Origin & 2 & 26.45 & 136.98 & 0.0001 & \multicolumn{2}{|l|}{ Bas $<\mathrm{PLN}=\mathrm{GdR}$} \\
\hline & Sex & 2 & 0.18 & 0.93 & 0.3894 & & \\
\hline & Origin $\times$ Sex & 4 & 1.30 & 6.75 & 0.0001 & \multicolumn{2}{|l|}{$\begin{array}{l}\text { Fem: } \text { Bas }<\text { PLN }=\text { GdR } \\
\text { Male: } \text { Bas }<\text { GdR }<\text { PLN } \\
\text { Juv: } \text { Bas }<\text { PLN }<\text { GdR }\end{array}$} \\
\hline & Res & 214 & 0.19 & & & & \\
\hline
\end{tabular}




\begin{tabular}{|c|c|c|c|c|c|c|c|}
\hline \multicolumn{8}{|c|}{ Contamination parameters } \\
\hline \multirow{4}{*}{$\begin{array}{l}\text { Hg (no covariate) } \\
\text { log }(X+1) \text { transf. } \\
\text { Euclidean dist. }\end{array}$} & Origin & 2 & 6.92 & 162.97 & 0.0001 & \multicolumn{2}{|l|}{ GdR $<$ PLN $<$ Bas } \\
\hline & Sex & 2 & 0.91 & 21.34 & 0.0001 & \multicolumn{2}{|l|}{ Juv $<$ Fem $<$ Male } \\
\hline & Origin $\times$ Sex & 4 & 0.13 & 3.07 & 0.0165 & $\begin{array}{l}\text { Fem: GdR }=\text { PLN }<\text { Bas } \\
\text { Male: } G d R<P L N<\text { Bas } \\
\text { Juv: } G d R=P L N<\text { Bas }\end{array}$ & $\begin{array}{l}\text { Bas: Juv }<\text { Fem = Male } \\
\text { GdR: Juv }<\text { Male }<\text { Fem } \\
\text { PLN: Juv }<\text { Fem }<\text { Male }\end{array}$ \\
\hline & Res & 215 & 0.04 & & & \multicolumn{2}{|l|}{$x^{2}$} \\
\hline \multirow{6}{*}{$\begin{array}{c}\text { Hg (Total length as a } \\
\text { covariate) } \\
\log (X+1) \text { transf. } \\
\text { Euclidean dist. }\end{array}$} & & & & & & & \\
\hline & Total length & 1 & 4.38 & 174.18 & 0.0001 & & \\
\hline & Origin & 2 & 8.04 & 319.40 & 0.0001 & \multicolumn{2}{|l|}{ Bas $<$ GdR $<$ PLN } \\
\hline & Sex & 2 & 0.33 & 13.18 & 0.0001 & \multicolumn{2}{|l|}{ Male $=$ Juv $<$ Fem } \\
\hline & Origin $\times$ Sex & 4 & 0.10 & 3.90 & 0.0048 & $\begin{array}{l}\text { Juv: } \mathrm{GdR}=\mathrm{PLN}<\text { Bas } \\
\text { Fem: } \mathrm{GdR}<\mathrm{PLN}<\text { Bas } \\
\text { Male: } \mathrm{GdR}<\mathrm{PLN}<\text { Bas }\end{array}$ & $\begin{array}{l}\text { Bas: Fem }<\text { Juv }=\text { Male } \\
\text { GdR: Juv = Male = Fem } \\
\text { PLN: Juv }<\text { Fem = Male }\end{array}$ \\
\hline & Res & 214 & 0.03 & & & \multicolumn{2}{|l|}{ 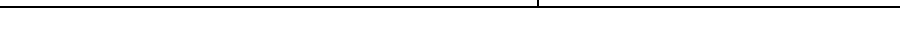 } \\
\hline
\end{tabular}

\begin{tabular}{|c|c|c|c|c|c|c|c|}
\hline \multirow{4}{*}{$\begin{array}{c}\text { CB } 153 \text { (no covariate) } \\
\log (X+1) \text { transf. } \\
\text { Euclidean dist. }\end{array}$} & Origin & 2 & 4.60 & 17.41 & 0.0001 & \multicolumn{2}{|l|}{ Bas $<\mathrm{PLN}=\mathrm{GdR}$} \\
\hline & Sex & 2 & 2.54 & 9.61 & 0.0002 & \multicolumn{2}{|l|}{ Juv $<$ Fem $<$ Male } \\
\hline & Origin $\times$ Sex & 4 & 2.97 & 11.24 & 0.0001 & $\begin{array}{l}\text { Juv: } P L N=\text { Bas }<\text { GdR } \\
\text { Fem: } \text { Bas }<\text { PLN }<\text { GdR } \\
\text { Male: } \text { Bas }=\mathrm{GdR}<\text { PLN }\end{array}$ & $\begin{array}{l}\text { Bas: Juv }=\text { Fem }<\text { Male } \\
\text { GdR: Juv }=\text { Male }<\text { Fem } \\
\text { PLN: Juv }<\text { Fem }<\text { Male }\end{array}$ \\
\hline & Res & 198 & 0.26 & & & & \\
\hline
\end{tabular}

\begin{tabular}{|c|c|c|c|c|c|c|c|}
\hline \multirow{5}{*}{$\begin{array}{c}\text { CB } 153 \text { (Total length as } \\
\text { a covariate) } \\
\log (X+1) \text { transf. } \\
\text { Euclidean dist. }\end{array}$} & TL & 1 & 9.39 & 39.33 & 0.0001 & & \\
\hline & Origin & 2 & 6.40 & 26.80 & 0.0001 & \multicolumn{2}{|l|}{ Bas $<\mathrm{GdR}<\mathrm{PLN}$} \\
\hline & Sex & 2 & 2.33 & 9.75 & 0.0002 & \multicolumn{2}{|l|}{ Fem $<$ Male $=$ Juv } \\
\hline & Origin $\times$ Sex & 4 & 2.38 & 9.95 & 0.0001 & $\begin{array}{l}\text { Juv: } P L N=\text { Bas }<\text { GdR } \\
\text { Fem: } \text { Bas }<\text { PLN }<\text { GdR } \\
\text { Male: } \text { Bas }=\text { GdR }<\text { PLN }\end{array}$ & $\begin{array}{l}\text { Bas: Juv }=\text { Fem }<\text { Male } \\
\text { GdR: Juv }=\text { Fem }<\text { Male } \\
\text { PLN: Juv }<\text { Fem }<\text { Male }\end{array}$ \\
\hline & Res & 197 & 0.24 & & & & \\
\hline
\end{tabular}


Table S3: Parameters of the regressions between total length (TL), $\delta^{15} \mathrm{~N}$ and $\mathrm{Hg}$ or PCB concentrations, and using linear or exponential regressions models.

The chosen model was the one with a significant correlation ("sig" column; ${ }^{* *}$ : p-value $\leq 0.001 ; * *$ : p-value $\leq 0.01 ; *$ : p-value $\leq 0.05 ;$ ns: non-significant, pvalue $>0.05$ ) and with the minimal AIC (Aikake Information Criterion). Model chosen is highlighted in grey.

\begin{tabular}{|c|c|c|c|c|c|c|c|c|c|c|c|c|}
\hline & \multicolumn{3}{|c|}{$\mathrm{Hg}=\mathrm{a} T L+b$} & \multicolumn{3}{|l|}{$\mathrm{Hg}=\mathrm{a} \mathrm{e}^{\mathrm{bTL}}$} & \multicolumn{3}{|c|}{$\mathrm{Hg}=\mathrm{a} \delta^{15} \mathrm{~N}+\mathrm{b}$} & \multicolumn{3}{|c|}{$\mathrm{Hg}=\mathrm{a} \mathrm{e}^{\mathrm{b} \delta 15 \mathrm{~N}}$} \\
\hline & Coeff. & AIC & Sig. & Coeff. & AIC & Sig. & coeff. & AIC & Sig. & Coeff. & AIC & Sig. \\
\hline Bastia & $\begin{array}{l}a=0.007 \\
b=-0.54\end{array}$ & 159.0 & $* * *$ & $\begin{array}{l}a=0.005 \\
b=-1.28\end{array}$ & 142.3 & $* * *$ & $\begin{array}{l}a=0.85 \\
b=-5.73\end{array}$ & 164.2 & $* * *$ & $\begin{array}{l}a=0.57 \\
b=-4.57\end{array}$ & 156.8 & $* * *$ \\
\hline Le Grau du Roi & $\begin{array}{l}a=0.002 \\
b=-0.13\end{array}$ & -99.4 & $* * *$ & $\begin{array}{l}a=0.005 \\
b=-2.76\end{array}$ & -108.1 & $* * *$ & $\begin{array}{l}a=0.21 \\
b=-1.69\end{array}$ & -67.7 & $* * *$ & $\begin{array}{l}a=0.68 \\
b=-7.77\end{array}$ & -71.2 & $* * *$ \\
\hline Port la Nouvelle & $\begin{array}{l}a=0.003 \\
b=-0.50\end{array}$ & 50.3 & $* * *$ & $\begin{array}{l}a=0.007 \\
b=-2.83\end{array}$ & 50.8 & $* * *$ & $\begin{array}{l}a=0.39 \\
b=-3.25\end{array}$ & 31.7 & $* * *$ & $\begin{array}{l}a=0.82 \\
b=-8.57\end{array}$ & 28.5 & $* * *$ \\
\hline
\end{tabular}

\begin{tabular}{|c|c|c|c|c|c|c|c|c|c|c|c|c|}
\hline & \multicolumn{3}{|c|}{$C B 153=a T L+b$} & \multicolumn{3}{|c|}{$C B 153=a e^{b T L}$} & \multicolumn{3}{|c|}{ CB153 $=a \delta^{15} \mathrm{~N}+\mathrm{b}$} & \multicolumn{3}{|c|}{$C B 153=a e^{b \delta 15 N}$} \\
\hline & Coeff. & AIC & Sig. & Coeff. & AIC & Sig. & Coeff. & AIC & Sig. & Coeff. & AIC & Sig. \\
\hline Bastia & $\begin{array}{l}a=0.02 \\
b=0.36\end{array}$ & 344.0 & ns & $\begin{array}{l}a=0.003 \\
b=0.65\end{array}$ & 343.7 & ns & $\begin{array}{l}a=1.59 \\
b=-8.03\end{array}$ & 302.7 & $* * *$ & $\begin{array}{l}a=0.24 \\
b=-0.34\end{array}$ & 303.0 & ns \\
\hline Le Grau du Roi & $\begin{array}{l}a=0.005 \\
b=-4.52\end{array}$ & 405.6 & $* * *$ & $\begin{array}{l}a=0.005 \\
b=-0.77\end{array}$ & 403.2 & $* * *$ & $\begin{array}{l}a=8.70 \\
b=-72.75\end{array}$ & 371.7 & $* * *$ & $\begin{array}{l}a=0.76 \\
b=-4.93\end{array}$ & 371.2 & $* * *$ \\
\hline Port la Nouvelle & $\begin{array}{l}a=0.05 \\
b=-2.91\end{array}$ & 457.2 & $* * *$ & $\begin{array}{l}a=0.003 \\
b=1.29\end{array}$ & 458.5 & $* * *$ & $\begin{array}{l}a=6.27 \\
b=-49.55\end{array}$ & 428.4 & $* * *$ & $\begin{array}{l}a=0.55 \\
b=-2.98\end{array}$ & 429.8 & $* * *$ \\
\hline
\end{tabular}


Fig. S1: Concentrations (ng g ${ }^{-1}$ dry mass) measured for the 8 PCB congeners analyzed, depending on the site and sex. All concentrations measured for $C B 28$ were below detection limits. Box hinges are the $1^{\text {st }}$ and $3^{\text {rd }}$ quartiles, line is the median value, and whiskers extend from the hinge to the highest or lowest value that is within $1.5 \times$ interquartile range. Points are outlier values.
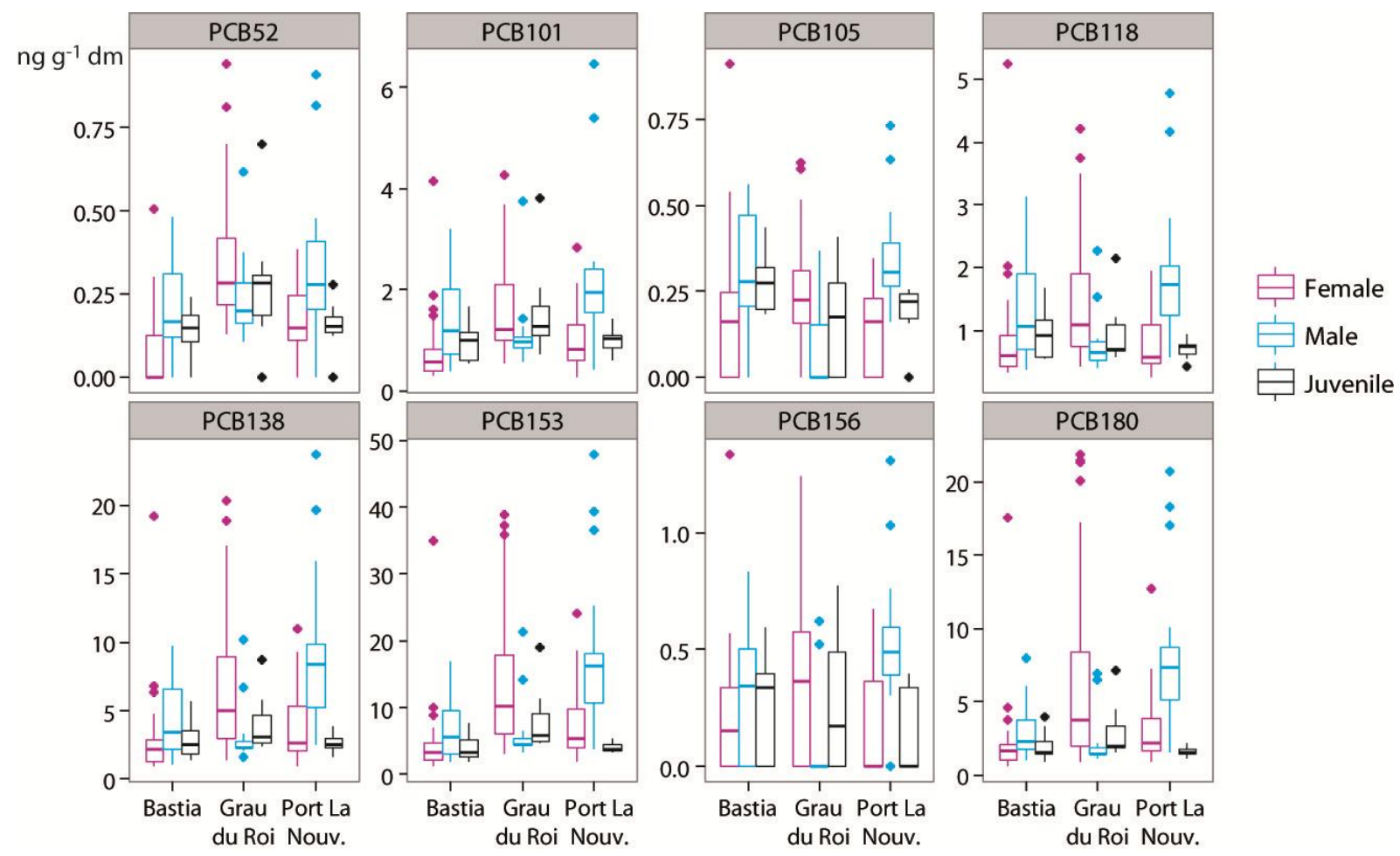
Fig. S2: First plan resulting from the CDA on Fourier coefficients calculated to describe otolith shape. Shape of the symbol refers to the maturity stage (circles: juveniles; diamond: adults) and color to the origin (white symbol with red border: Bastia, grey symbol with green border: Le Grau du Roi, black symbol with blue border: Port la Nouvelle). For graphic purposes, name of the sampling site and maturity stages were abbreviated (BAS: Bastia, GDR: Le Grau du Roi, PLN: Port la Nouvelle; Juv: Juvenile, Ad: Adults). Euclidean distances between barycenter of each group are provided in the lower-left corner table.

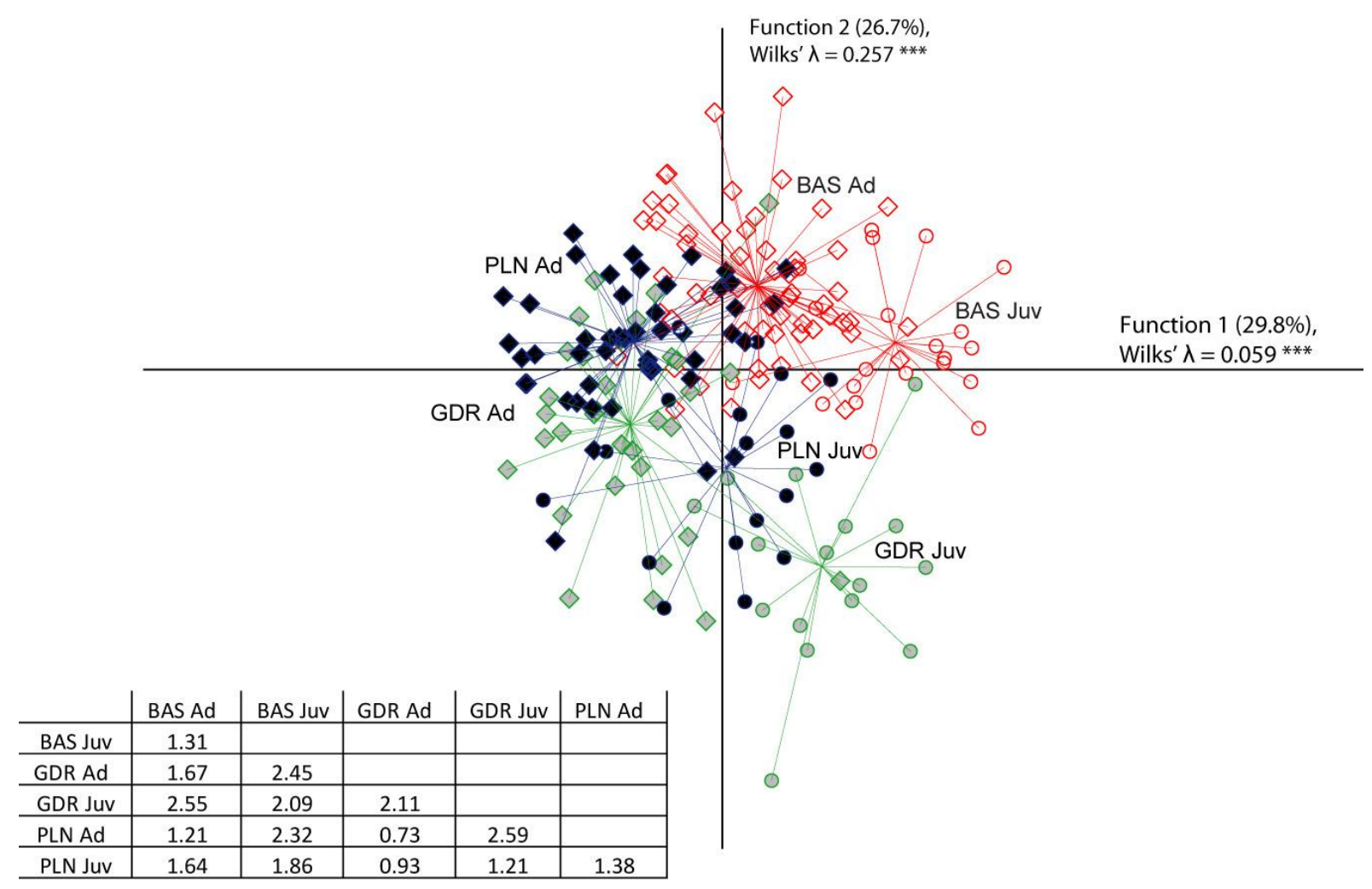

